\title{
REVIEW
}

\section{Temperature and substrates as interactive limiting factors for marine heterotrophic bacteria}

\author{
Lawrence R. Pomeroy ${ }^{1, *}$, William J. Wiebe ${ }^{2}$ \\ ${ }^{1}$ Institute of Ecology, University of Georgia, Athens, Georgia 30602-2202, USA \\ ${ }^{2}$ Department of Marine Sciences, University of Georgia, Athens, Georgia 30602-3636, USA
}

\begin{abstract}
Active heterotrophic bacterial communities exist in all marine environments, and although their growth rates or respiratory rates may be limited by the interaction of low substrate concentrations with temperatures near their lower limit for growth, temperature and substrate concentrations are rarely considered together as limiting factors. Moreover, attempts to evaluate metabolic limits by both temperature and substrate concentration have sometimes led to confusing conclusions, because, while we can measure dissolved organic carbon (DOC) concentrations in natural waters, much of it is not readily available to heterotrophic bacteria. In spite of this procedural limitation, it can be helpful to regard temperature and substrate concentration as potential limiting factors that interact. In temperate ocean surface waters and estuarine waters, where bacterial growth is often reduced in winter, growth and respiration may be increased experimentally either by raising the temperature or by increasing organic substrate concentrations, providing indirect evidence that the limitation is an effect of temperature on substrate uptake or assimilation. Experimental work with bacterial isolates also has shown a temperature-substrate interaction. In permanently cold polar waters, most heterotrophic bacteria appear to be living at temperatures well below their optima for growth. Nevertheless, bacteria in permanently cold surface waters can achieve activity rates in summer that are as high as those in temperate waters. In sea ice, rates of bacterial production are most often low, even though concentrations of substrates, including free amino acids, are sometimes much higher than they are in seawater. This suggests that at sea ice temperatures heterotrophic bacteria have lowered ability to take up or utilize organic substrates.
\end{abstract}

KEY WORDS: Temperature $\cdot$ Substrates $\cdot$ Heterotrophic bacteria $\cdot$ Limiting factors

\section{INTRODUCTION}

Justus Liebig (1840) revolutionized agriculture with the observation that growth of plants is limited by the essential element present in the least quantity relative to the plant's requirement for it. Ecologists adopted Liebig's law of the minimum, extrapolating it to all sorts of natural populations of organisms and even to entire ecosystems (Ryther \& Dunstan 1971). Although ecologists, and even Liebig, recognized that multiple limiting factors may interact and result in different out-

*E-mail: lpomeroy@uga.edu comes, there remains a tendency to seek the limiting factor for growth or metabolism of populations of organisms or ecosystems (e.g. Behrenfield et al. 1996). This is, in part, owing to the difficulty of dealing simultaneously with 2 or more variables, especially in observations on natural communities, where controlled experiments are difficult.

Temperature, like essential chemical elements and organic substrates, is always a potentially limiting factor. In particular, temperature should be viewed as an ever-present, interactive factor, because it affects all chemical and biochemical processes. Every bacterial phylotype has minimal, maximal and optimal tempera- 
ture characteristics, the so-called cardinal temperatures. $Q_{10}$ values tend to be 2 to 3 , except near the temperature limits for growth of an organism. What is less well-recognized is that the response of an organism to a given temperature may vary depending on other factors as well as the converse: limiting factors may be temperature-dependent as well as concentration-dependent. At temperatures approaching the lower limit for growth, the substrate-temperature relationship becomes non-linear, as shown in Fig. 1. In some circumstances, excess substrate overrides temperature effects (Nedwell \& Rutter 1991, Pomeroy et al. 1991). So, while temperature is always a factor in microbial growth, respiratory rate, and organic carbon assimilation, it is not always the only factor or even a dominant one. We review evidence for interaction between temperature and the utilization of organic substrates by heterotrophic bacteria in natural waters. In treatise after treatise, we find separate chapters on temperature effects (Rivkin et al. 1996), on substrates (Button 1986), and on

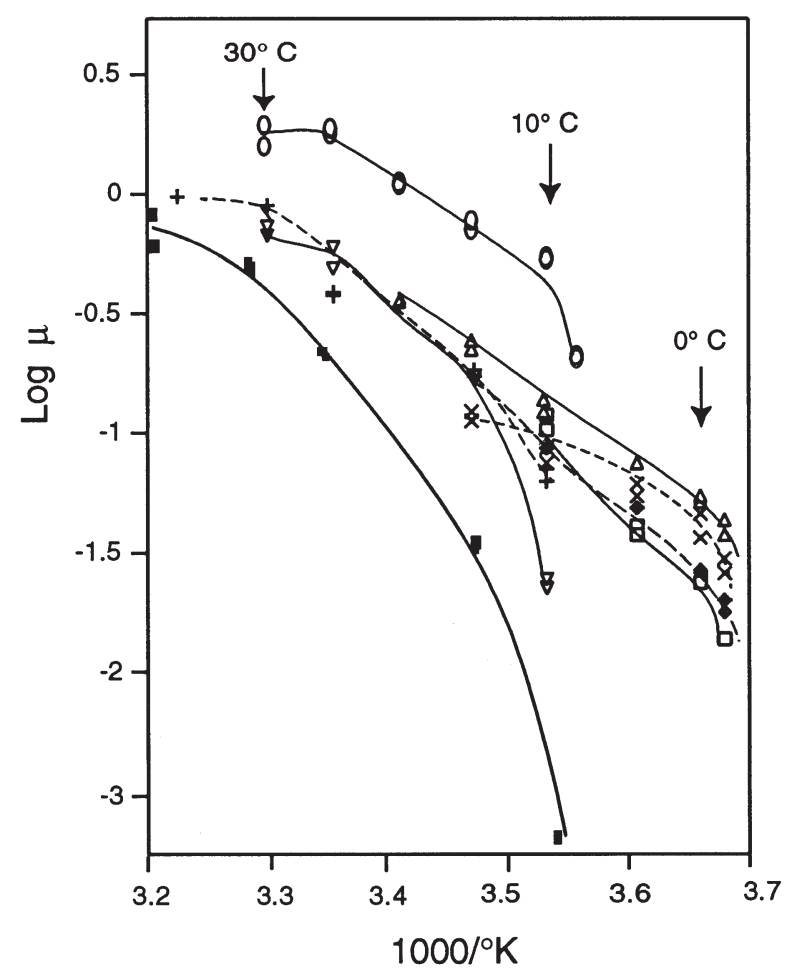

Fig. 1. Arrhenius plots of isolates from various latitudes: GS-10 (0) from the outer US continental shelf $\left(31^{\circ} 52^{\prime} \mathrm{N}\right.$, $\left.80^{\circ} 10^{\prime} \mathrm{W}\right), 5 \mathrm{~m}$ depth; GG-7 $(\nabla)$ from the Gulf Stream at $31^{\circ} 50^{\prime} \mathrm{N}, 79^{\circ} 16^{\prime} \mathrm{W}, 40 \mathrm{~m}$ depth; N-3 $(\Delta)$ and N-5 ( $\square$ ) from a $25 \mathrm{~m}$ sample in April in Conception Bay, Newfoundland $\left(47^{\circ} 32^{\prime} \mathrm{N}, 53^{\circ} 08^{\prime} \mathrm{W}\right)$; I5 $(\times)$; I-120 ( $\left.\diamond\right)$ from water collected in June under $2 \mathrm{~m}$ of sea ice at $79^{\circ} 37^{\prime} \mathrm{N}, 108^{\circ} 51^{\prime} \mathrm{W}$; Escherichia coli (回); JW-4 (+), a previously unpublished isolate from coastal Jamaica. All isolates were grown in aged seawater supplemented with proteose-peptone and yeast extract, $0.15 \mathrm{mg} \mathrm{l}^{-1}$ (1.5 $\mathrm{mg} \mathrm{l}^{-1}$ for E. coli). Data from Wiebe et al. $(1992,1993)$ essential elements (see also Ducklow \& Shiah 1993), so we view a discussion of their interaction as a relatively neglected subject, although the recent publications of Nedwell $(1999,2000)$ and Reay et al. (1999) make important contributions to this subject.

\section{THEORY AND EXPERIMENTS}

\section{Temperature as a rate limit}

In a broadly ranging theoretical analysis of the effect of temperature on biological rate processes, from bacteria to trout, Quinlan (1980) defined the relationship between Michaelis-Menten kinetics and temperature as 'fully described by a one-parameter family of either isotherms or isoconcentrations such that optimum temperature increases linearly as the logarithm of the substrate concentration, following the Arrhenius temperature laws.' However, she made the significant statement that this is limited to (1) single-factor relationships and (2) events within the 'normal range' of biological activity. Quinlan defined the temperature range of biological activity as 0 to $50^{\circ} \mathrm{C}$. It is, of course, broader than this, but the observations and experiments that she cites mostly did not cover even that range. In Quinlan's examples, $Q_{10}$ was 2 to 3 and was a log-linear function of temperature within the functional temperature range of an organism, becoming larger and non-linear at temperatures near the growth limit and largest when low temperatures combine with low substrate concentrations (cf. Quinlan 1981, her Fig. 4) This interaction of substrates and temperature was also seen in the data of Harder \& Veldkamp (1971) and those of Wiebe et al. $(1992,1993)$ in which organisms were cultured down to a no-growth temperature. At temperatures approaching zero growth for an organism, double-digit $Q_{10}$ values are seen. This effect appears to be associated with a decrease in assimilation efficiency (Morita \& Buck 1974). In the typical Arrhenius plot of changes in rate processes with temperature, rates hook downward at either end of the 'normal' temperature range for the enzyme or organism studied. Fig. 1 illustrates temperature responses at a substrate concentration of $75 \mu \mathrm{g} \mathrm{C}^{-1}$ by isolates from various latitudes. The tropical-subtropical isolates mostly show deviations from linearity around $10^{\circ} \mathrm{C}$, while the temperate-polar isolates show deviations from linearity near $0^{\circ} \mathrm{C}$. Natural populations are commonly subject to limiting extremes of temperature such as these, and heterotrophic bacteria in natural waters probably are often presented with sub-optimal concentrations of substrates (Nedwell 1999).

It is frequently argued that bacteria growing at maximal rates are likely to be the exception rather than the 
rule in many aquatic environments, even if the dominant populations are, as Button et al. (1998) suggest, very small organisms with simultaneous high affinity for several specific substrates. In contrast to that viewpoint, it has been suggested on theoretical grounds that substrate concentration normally should not be limiting to heterotrophic bacteria in the upper mixed layer (Thingstad \& Lignell 1997, Williams 2000). Observations and experiments suggest that at least some heterotrophic bacteria have the ability to adjust their growth rate and body size according to the substrate concentration present (Wiebe \& Pomeroy 1972, Novitsky \& Morita 1976) and, in the absence of temperature co-limitation, may be growing at near-maximum rates in both eutrophic and oligotrophic environments. Resolution of this question may await confirmed culture of the dominant bacterial populations in the ocean as discussed below in 'Methodological considerations'. Meanwhile, experimental and observational data suggest that limiting temperatures can affect substrate utilization by heterotrophic bacteria.

\section{Observations and experiments}

Two approaches are commonly used to examine the interaction of temperature with other potentially limiting factors. One is experimental manipulation of either axenic cultures of microorganisms or natural communities of microorganisms, and the other is a statistical examination of large sets of observations of events in natural waters. Using the statistical approach, Cole et al. (1988) examined the literature on bacterial responses to substrate concentration (or to net primary production) without regard to temperature as such, finding that in general there is a correlation between bacterial production and chlorophyll a (chl a) concentration $\left(\mathrm{r}^{2}=0.57\right)$. Rivkin et al. (1996) reviewed bacterial production versus temperature, without regard to substrate concentration, from data in 68 previous publications. They reported a very weak overall relation of bacterial production to temperature. White et al. (1991) examined the relationship between heterotrophic bacterial abundance, production, and water temperature from data in 57 previous studies, using chl $a$ as a surrogate for substrate concentration. In marine waters, they found a significant relationship between specific bacterial growth rate, temperature and chl $a$ concentration $\left(r^{2}=0.56\right)$.
Using pure cultures in chemostat experiments, Harder \& Veldkamp (1971) ran 2-factor competition experiments between a psychrophilic Pseudomonas sp. and a psychrotolerant Spirillum sp. At $16^{\circ} \mathrm{C}$, the Spirillum sp. grew faster at all substrate concentrations; at $-2^{\circ} \mathrm{C}$, the Pseudomonas sp. grew faster at all substrate concentrations; at intermediate temperatures, the psychrotolerant Spirillum sp. was able to grow faster at low substrate concentrations and the psychrophilic Pseudomonas sp. at high substrate concentrations. Although there were small differences in slope of the response of growth rates of the 2 isolates, the different responses were primarily the result of different inflection points in the Arrhenius plot. The psychrotolerant strain had twice the linear temperature range, but the psychrophile's range extended to the freezing point of seawater. Experimenting with isolates from Antarctic sea ice, Helmke \& Weyland (1995) showed that survival of psychrophiles in the ice depends on their affinity for substrate at sea-ice temperatures. Wiebe et al. $(1992,1993)$ measured growth rates of bacterial isolates from subtropical to polar environments in a matrix of substrate concentrations and temperatures (Fig. 2). Every isolate shows a dis-

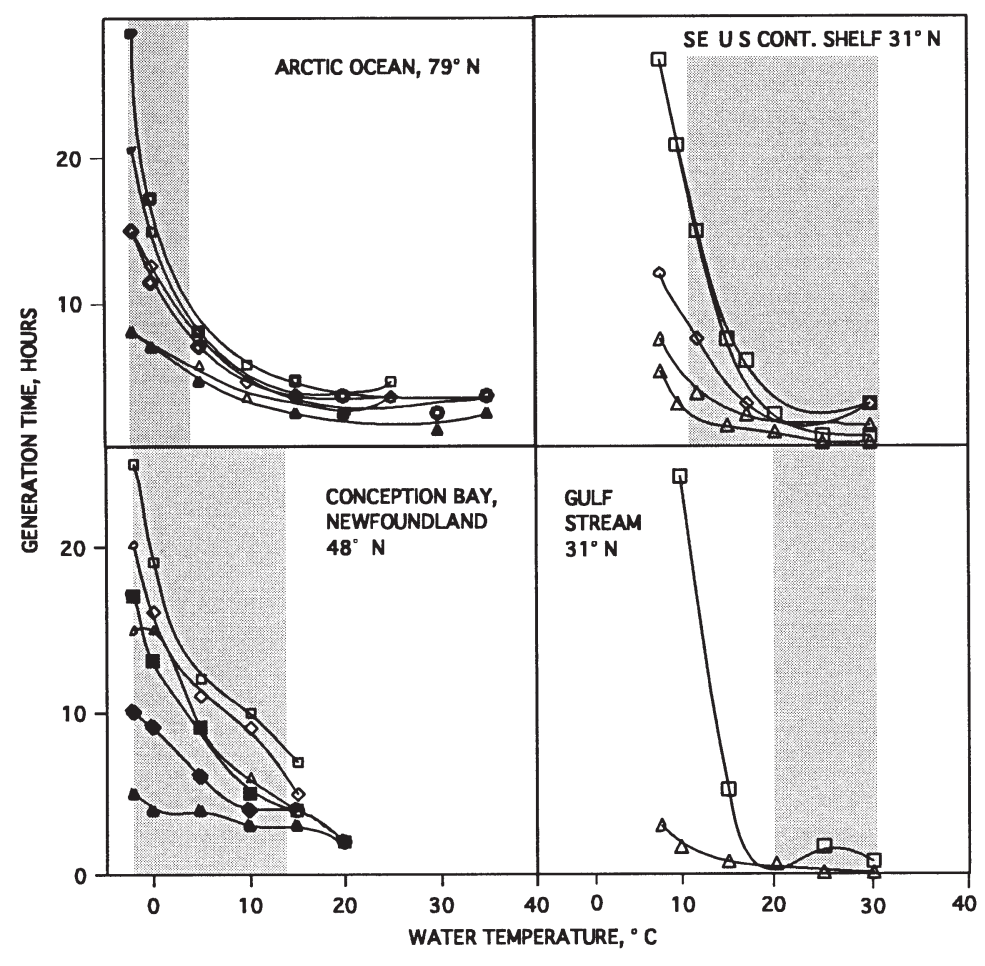

Fig. 2. Plots of growth rate versus temperature for 2 isolates from each of 3 locations, plus 1 from the Gulf Stream off Georgia, USA, grown in batch culture at proteose-peptone-yeast extract concentrations of $0.15 \mathrm{mg} \mathrm{l}^{-1}$ $(\boldsymbol{\square}, \square), 1.5 \mathrm{mg} \mathrm{l}^{-1}(\diamond, \diamond)$, and $1500 \mathrm{mg} \mathrm{l}^{-1}(\boldsymbol{\Delta}, \Delta)$. The shaded areas delineate the annual range of water temperature in the mixed layer at that location. Filled and open symbols distinguish the 2 isolates in each case. Data from Wiebe et al. $(1992,1993)$ 
tinct substrate-temperature interaction. These results can be visualized as a response surface in 3-dimensional plots, such as those in Fig. 3. The response surface for Escherichia coli also has been shown in Fig. 1 of Wiebe \& Pomeroy (2000). While all response surfaces have the same general form, the details are significantly different. There is some combination of sub-
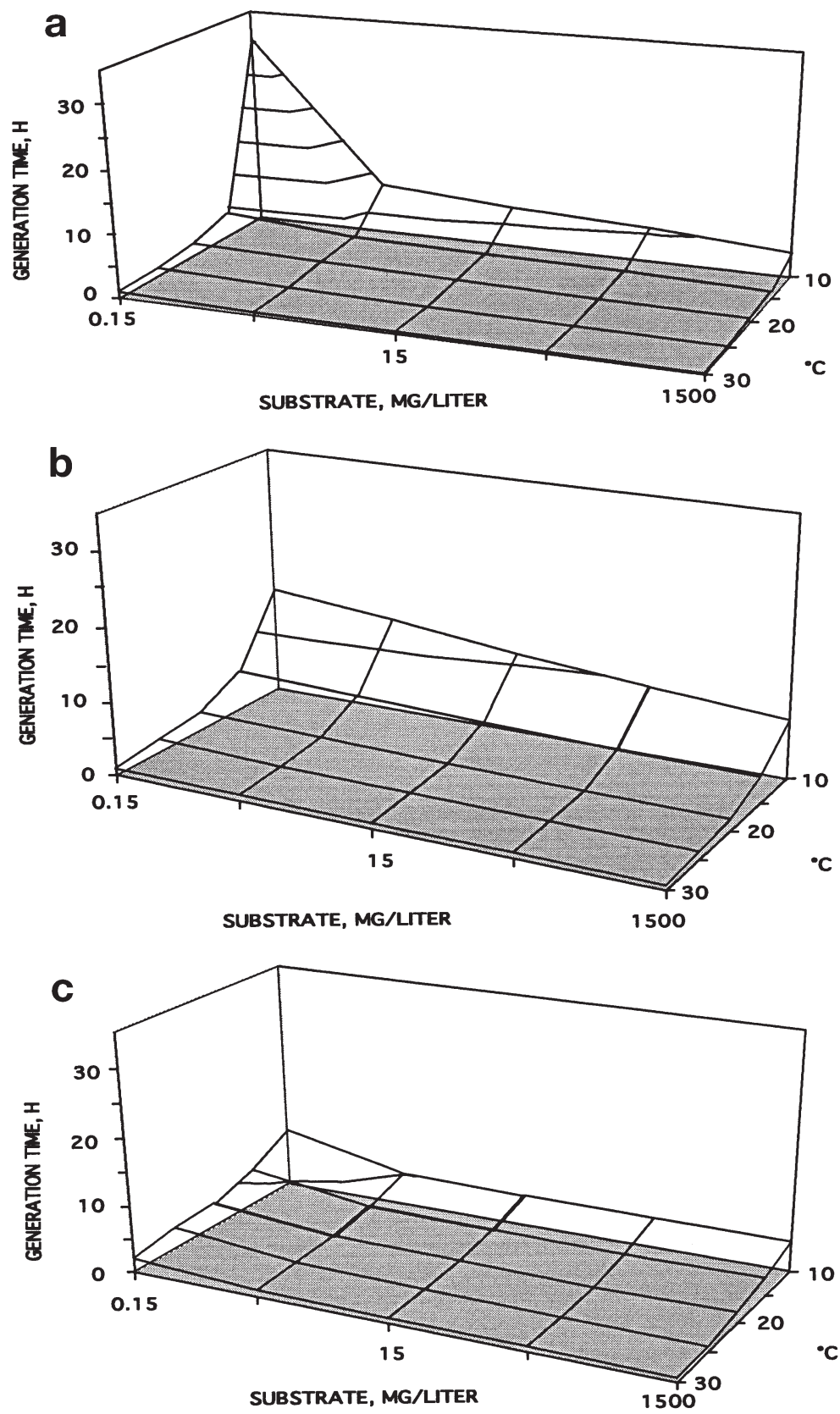

Fig. 3. (a) Responses of isolates GG-7 from $40 \mathrm{~m}$ depth in the Gulf Stream at $32^{\circ} \mathrm{N}$, ambient temperature $20^{\circ} \mathrm{C}_{i}$ (b) JW-4 from coastal Jamaica, ambient temperature $26^{\circ} \mathrm{C}_{\text {; }}$ and (c) BF9212-5 from the mouth of Wassaw Sound, Georgia, ambient temperature $12^{\circ} \mathrm{C}$, to experimental variations in temperature and substrate concentration. See text for discussion. Data from Wiebe et al. (1993) strate and temperature at which each organism can grow faster than the others. So, like the isolates of Harder \& Veldkamp (1971), there are combinations of temperature and substrate favorable to each.

Experiments with natural communities also have demonstrated temperature-substrate interactions. Gillespie et al. (1976) found that uptake of ${ }^{14} \mathrm{C}$-glutamic acid ( 1 to $4 \mu \mathrm{g} \mathrm{l}^{-1}$ ) by Antarctic microbial communities sampled at 60 to $65^{\circ} \mathrm{S}$ was a nonlinear function of temperature. Griffiths et al. (1984) found a positive correlation between temperature and percent respiration of glucose or glutamate added to natural microbial communities from the Beaufort Sea, with respiratory rates measurable down to $-1.8^{\circ} \mathrm{C}$. Pomeroy et al. (1991) examined the effect of a matrix of temperatures and substrate concentrations on respiratory rates of natural microbial assemblages taken from Newfoundland waters and found a significant temperaturesubstrate interaction. In an alpine lake, Morris \& Lewis (1992) found evidence of a phosphorus-temperature interaction but not an organic carbon-temperature interaction. This latter study highlights the potential for interactions of multiple limiting factors. Since most of the experiments reported in the literature consider 1 or at most 2 factors, this may explain some of the resulting inconsistencies.

In addition to the above demonstrations of the interaction of metabolic activity of heterotrophic bacteria with substrate concentration and temperature, the literature contains many instances where this relationship apparently does not appear to hold. Some of these investigators failed to note that changes in substrate concentration of orders of magnitude are often necessary to maintain microbial activity at temperatures near the lower temperature limit for isolates or natural communities and thus may have failed to add enough substrate in their experiments to demonstrate increased bacterial growth (e.g. Rivkin et al. 1991, Felip et al. 1996, Autio 1998, Yager \& Deming 1999). Some investigators initially added excess substrate and were thus unable to show any inhibition of growth at lower temperature (Delille \& Rosiers 1995, Helmke \& Weyland 1995). Others made observations on potentially substrate-rich and nutrient-rich systems such as shallow water bodies and benthic sediments where one might not expect to find substrate limitations and a consequent sensitivity to temperature changes (e.g. Deming \& Yager 1992). In both sediments (Glud et al. 1998) and 
eutrophic water (Li \& Dickie 1987, Reitner et al. 1997) some investigators found no relationship between bacterial production and temperature, while others (Bell \& Ahlgren 1987, Robarts et al. 1991), investigating eutrophic lakes, did. Recently, Yager \& Deming (1999) performed a series of substrate-temperature experiments with bacterial communities from the waters of the Northeast Water polynya, some of which showed a temperature-substrate interaction, while other samples did not. In this case, it should be noted that the range of added amino acids was up to a maximum of only twice that analytically present in the water, and the experimental temperature range was only $6^{\circ} \mathrm{C}$. Thus, some responses by psychrotolerant populations that were less sensitive to both temperature and substrate concentration likely were missed.

\section{Methodological considerations}

A note of caution is necessary with regard to extrapolating responses of pure cultures to natural communities. In recent years, a new approach to identifying bacterial species in the ocean has arisen using molecular methods. This approach has the advantage that bacteria do not have to be cultured in order to be identified, and this is, perhaps, particularly important, since in the early investigations only a few percent of the bacteria counted by direct microscopic techniques grew in culture media. Pioneer work by Fuhrman (1992), Giovannoni et al. (1993), Fuhrman et al. (1993), and DeLong et al. (1994) concluded that most of the Bacteria (and Archaea) in the sea, as identified by a variety of molecular techniques, do not belong to the taxa grown on culture media. This finding tended to reinforce the earlier observation that plate counts are much smaller than direct counts (Jannasch \& Jones 1959). Since these early molecular studies, other investigators (e.g. Eilers et al. 2000) have confirmed their results, while some recent studies dispute them (Rehnstam et al. 1993, González et al. 1996, González \& Moran 1997, Pinhassi et al. 1997, Hagström et al. 2000, Pinhassi \& Hagström 2000).

Rehnstam et al. (1993) made 16S rRNA probes from 14 isolates from water at Scripps Pier in southern California. When natural samples were challenged seasonally with the probes, cultured organisms proved to be dominant during the season of isolation and again at the same season the following year. In the Northern Baltic, Pinhassi et al. (1997) isolated 48 strains on ZoBell agar (Marine agar, Difco Laboratories, Detroit, MI, USA), labeled their DNA with ${ }^{32} \mathrm{P}$, and hybridized it with field samples. Their results suggested that the majority of the dominant bacteria, most of the time, were culturable on replete media. Rehnstam et al.
(1993) suggesed that the low plating efficiency that is often observed may be the result of lysogenic viral infections (e.g. Proctor \& Fuhrman 1990), which may enter a lytic phase upon a shift-up of bacterial metabolism on culture media, rather than the result of specific unmet culture requirements. This hypothesis would seem to be compatible with the observations of Button et al. $(1993,1998)$ that more species of bacteria can be cultured on unamended seawater. Recently, several investigators have suggested that communities of heterotrophic bacteria in the sea are dominated by relatively few, mostly culturable, species which undergo regular, repeatable seasonal successions (González et al. 1996, González \& Moran 1997, Hagström et al. 2000, Pinhassi \& Hagström 2000). Significantly, all of these studies were performed in coastal or estuarine waters.

The taxonomic discrepancies noted above are unresolved. Unfortunately, few of the 'new' species of Bacteria and Archaea have been isolated in pure culture. The lack of isolation in culture presents a potential problem, since investigators who make observations about in situ bacterial growth and metabolism use culture data to interpret their results, albeit cultures isolated either from unamended seawater (Button et al. 1993) or from aged seawater amended with substrate concentrations in the analytical range of those in seawater (Wiebe et al. 1992, 1993). If the bacteria that have been identified by molecular techniques, but not subsequently isolated, do sometimes comprise the majority of in situ bacterial biomass and activity, and if they have physiological and biochemical characteristics different from bacterial cultures, then there might be a mismatch of data which could greatly affect the interpretation of bacterial metabolism in the sea. Button et al. (1998) report that $85 \%$ of the bacteria-like particles they detected by flow cytometry are smaller than the smallest organism they have thus far been able to culture, which could support either the mismatch hypothesis or the starvation-survival hypothesis (Novitsky \& Morita 1976). So it is probably fair to report that currently there are 2 interpretations of the existing data and experiments, insufficient evidence exists to falsify either one, and a number of contradictions need to be resolved. It may be, of course, that some waters, under some conditions, contain higher numbers of culturable bacteria than others (e.g. eutrophic vs oligotrophic water, pre-bloom vs post-bloom water). A 'one size fits all' model may not suffice.

In temperate regions of the ocean, there have been some disagreements on the interpretation of in situ bacterial metabolic data (e.g. Pomeroy et al. 1991, Rivkin et al. 1996). While some of these disputes are based on methodology, as discussed elsewhere in this review, other problems may arise from the use of cul- 
ture data to interpret the in situ results. The discussion that follows can only be based on present-day information, but the reader should be aware of the possibility that we are using a skewed representation of the metabolism of the bacteria in the sea. Furthermore, when investigators examine the cardinal temperatures of those bacteria that can be isolated from permanently cold areas of the ocean, a perplexing problem arises. In many, but not all, cases in Arctic, Antarctic, and deepocean waters, a preponderance of psychrotolerant bacteria are isolated, growing at temperatures well over the $20^{\circ} \mathrm{C}$ maximum growth temperature that defines psychrophiles (Wiebe \& Hendricks 1974, Upton \& Nedwell 1989a, Ruger \& Tan 1992). In a number of pure culture studies, investigators have shown in a variety of ways that, while psychrophiles appear to be better adapted for permanently cold conditions, competitive success depends upon available substrate concentrations, with psychrotolerant isolates competing better at the low substrate conditions that often prevail (e.g. Harder \& Veldkamp 1971).

Two factors could confound interpretation of the psychrophile versus psychrotolerant data. First, until recently almost all isolations of marine bacteria were accomplished using standard culture media such as ZoBell 2216 marine agar and broth, which contains $5 \mathrm{~g}$ of peptone and $1 \mathrm{~g}$ of yeast extract per liter. It is now recognized that many more bacteria can be cultured if the nutrient concentration is reduced to the range of substrate concentrations we expect to find in natural seawater (Button et al. 1993; Table 1). These previously uncultured bacteria appear to have a versatile metabolism (Upton \& Nedwell 1989b, Button et al. 1993, 1998, Rutter \& Nedwell 1994, Wiebe et al. unpubl. data). Further, a much larger number of the isolates from conventional media are psychrotolerants. Thus, methodology that was more appropriate in the pathology laboratory than in the ocean may have skewed the results, and scrutiny of some older data is warranted.

The second factor that could be operating is the continual rain of bacteria through the water column to the deep, cold ocean attached to particulate matter originating in the surface waters. Many investigators have measured quantitatively the descent of particles from the surface, and these may contain surface-dwelling or even terrestrial microorganisms (Billet et al. 1983, Fuhrman \& Azam 1983). Rex et al. (1993), and more recently Cronin \& Raymo (1997), documented that biodiversity of several taxa of abyssal benthic animals shows a latitudinal gradient, with progressively fewer species at higher latitudes, just as occurs in terrestrial

Table 1. Recent measurements of potentially labile constituents of organic matter in natural waters, sediments and ice. DFAA = dissolved free amino acids; DCAA = dissolved combined amino acids; 'Carbohydrates' may be variously analyzed for one or a spectrum of compounds. Original units of measure have been preserved, because conversion to a common metric would involve assumptions about the molarity of mixed and sometimes undefined organic materials. Summaries of older data can be found in Romankevich (1984) and Thurman (1985)

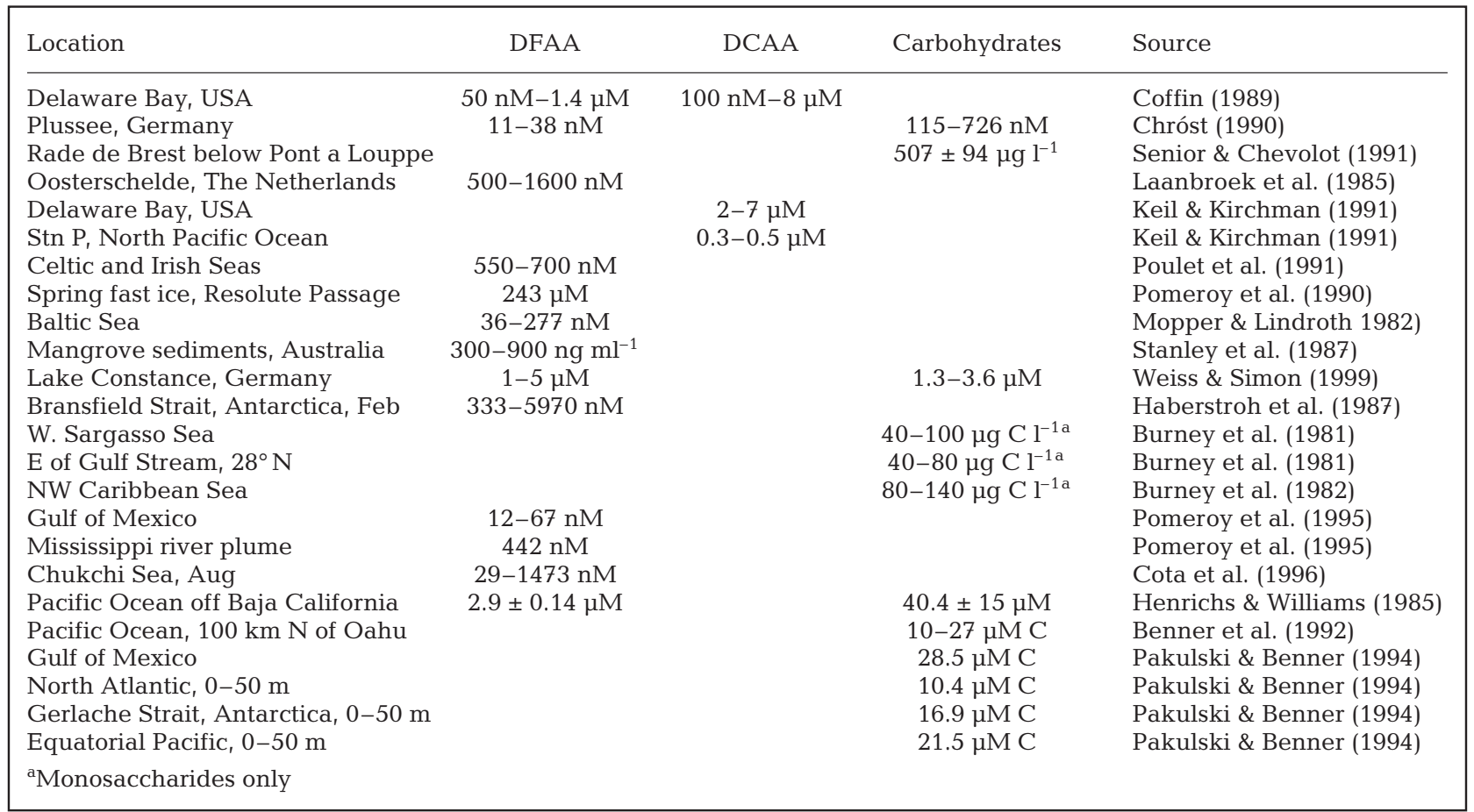


environments. They concluded that this must be related to events in the upper mixed layer. Thus, not all of the bacteria that we capture and culture may have been long-time residents of the cold ocean but instead may have recently arrived from the mixed layer or elsewhere. Bacteria are redistributed in the ocean much more rapidly than hydrography alone would predict (Hagström et al. 2000).

Both of these factors could provide an explanation for the presence of so many psychrotolerant isolates in permanently cold waters. Nevertheless, the existing, though limited, experimental data with axenic cultures and natural bacterial communities suggest different responses to temperature-substrate interaction by bacteria at different latitudes (Fig. 2) and even specific location (Robarts et al. 1991). Interpreting the experimental data in terms of real-world responses requires knowledge of naturally occurring temperatures and concentrations of labile substrates (Robarts et al. 1991). While the latter cannot be known absolutely, it may be possible to set some tentative limits on the basis of the concentrations of dissolved free and combined amino acids and monosaccharides in seawater. One approach, short-term measurements of the fraction of the pool of total dissolved organic matter that is utilized, may be instructive, but the results have been mixed (e.g. Wiebe \& Smith 1977, Hansell et al. 1995, Børsheim 2000). It appears that a pool of rapidly utilized DOC is supplemented by varying amounts of less labile DOC that may have turnover times of months or longer.

Concentrations of available substrates cover a range of several orders of magnitude in natural waters. In estuaries, total amino acids, peptides, proteins, and simple carbohydrates range from $<10 \mu \mathrm{g} \mathrm{C}^{-1}$ to $4 \mathrm{mg}$ $\mathrm{C}^{-1}$ (Table 1). The experiments described in Fig. 2 offer a provisional model for evaluating temperaturesubstrate interaction in a variety of situations, given the approximately known range of substrate concentrations. In the ocean, the estimated range of total amino acids, peptides, proteins, and simple carbohydrates is 50 to $250 \mu \mathrm{g} \mathrm{C} \mathrm{l}^{-1}$. Not all of these compounds are readily labile, as estimated by short-term utilization experiments, and the labile and semi-labile fractions combined constitute perhaps $<10$ to $>50 \%$ of the total concentration (Hansell et al. 1995, Weiss \& Simon 1999, Søndergaard et al. 2000). The observed range of concentrations of available substrates, based on the above observations, covers a range similar to that used in the enrichment experiments of Wiebe et al. (1992, 1993). Without knowing the substrate concentration present in any specific environment at any particular time, however, we can only speculate that the interaction of temperature and substrate concentration controls bacterial productivity near the low end of their range of temperature tolerance, as has been shown experimentally (Pomeroy et al. 1991, Wiebe et al. 1993, Rutter \& Nedwell 1994).

While dominant organisms can be selected seasonally by temperature changes (Sieburth 1967), they do so within limits (Fig. 2). In the tropics, heterotrophic bacteria are mostly operating near their optimum temperature for growth (Morita 1974). In the subtropics, temperature is somewhat suboptimal in winter. In temperate latitudes, bacteria may approach no-growth temperature in winter, but heterotrophs may also be limited by lower rates of production of DOC and particulate organic carbon (POC) by phytoplankton in winter as the result of lower light intensity and deep mixing, and these limiting factors may interact synergistically with lower temperature. In polar waters, within the normal range of available substrates, heterotrophic bacteria rarely experience optimal temperatures for growth but may reach a no-growth condition only when brine pockets freeze in winter sea ice (Fig. 2). In other words, the ultimate limit for growth is the presence of liquid water in and around bacteria.

A further methodological consideration involves continuing modifications of the methods of measuring bacterial production. To evaluate temperature effects on natural bacterial communities, investigators commonly measure rates of bacterial production by the incorporation of either tritiated thymidine (Tdr) or tritiated leucine (leu). Understanding and evaluating these methods is an important issue for this review, since so many investigators use them. It is now recognized that early estimates of bacterial production, using either Tdr or leu at final concentrations of $5 \mathrm{nM}$ (and occasionally less, e.g. Fuhrman \& Azam 1980) did not saturate uptake rates, and therefore the data in many publications were underestimates (Logan \& Fleury 1993, van Looij \& Riemann 1993). While many of the early Tdr uptake measurements used a conversion factor developed by Fuhrman \& Azam (1980), investigators have begun calibrating Tdr uptake against dilution experiments on the waters being studied following the procedures of Kirchman et al. (1982). It should be recognized that using dilution cultures to 'correct' Tdr assimilation amounts to using dilution cultures to estimate bacterial production. When corrections are made infrequently, significant error may be incorporated in estimates of production based on Tdr uptake. It is important when evaluating earlier work to take note of methodology and to identify deviations from current practice. Relative changes in Tdr or leu uptake within a sequence of experiments may be significant even if absolute concentrations of the tracer are in error. Also, where older work is imprecise, the bounds of error sometimes can be approximated, and very large differences may still have significance (Chranowski 1988). 
Before dismissing older data, we should examine them critically and salvage what we can.

\section{TEMPERATURE AND SUBSTRATES IN NATURAL WATERS}

A relatively small number of investigators have set out to describe the interactions of temperature and substrate concentrations on natural communities of heterotrophic bacteria. However, a number of investigations having other principal goals also provide data that may shed some light on this interaction. As Fig. 2 suggests, heterotrophic bacteria may be responding differently in temperate water, permanently cold regions, and sea ice.

\section{Temperate waters}

If the relationships in Fig. 2 constitute a valid generalization, interaction of temperature with substrate availability should be most obvious in temperate waters in winter; this is indeed a frequent finding (Carney \& Colwell 1976, Hagström \& Larsson 1984, Admiraal et al. 1985, Bell \& Ahlgren 1987, Scavia \& Laird 1987, Nielsen \& Richardson 1989, Malone \& Ducklow 1990, Shiah \& Ducklow 1994a,b). Since spring phytoplankton blooms commonly begin while the water is still near its minimum temperature, our hypothesis suggests that low bacterial production should be seen in early stages of the spring bloom, and several examples have been reported (Billen \& Fontigny 1987, Lancelot et al. 1989, Nielsen \& Richardson 1989, Bird \& Karl 1999). Reduced bacterial production in early stages of phytoplankton blooms may involve not only some inhibition by low temperature as a requirement for a higher substrate concentration, sensu Nedwell (1999), but also a lag phase prior to the onset of bacterial division which may last from a day to a month (Hollibaugh 1979, Griffiths et al. 1982, Helmke \& Weyland 1986, Lancelot et al. 1989, Autio 1998). It may also reflect the presence of a relatively small population of grazers in early stages of some temperate spring blooms producing little regeneration of substrates by way of excretion, defecation, and sloppy feeding as suggested by Jumars et al. (1989).

Other factors also potentially complicate this paradigm. One can argue, for example, that different bacterial phylotypes with different cardinal temperatures will be dominant in temperate waters at different seasons (Sieburth 1967, Poremba et al. 1999). Yet, the above citations show many instances where bacterial communities appear to be limited by the interaction of seasonal changes in temperature with the availability of substrates. Cotner et al. (2000) found that bacterial production in Lake Michigan in mid-winter was raised to rates comparable to mid-summer when sediments were suspended following a storm. In the southeastern USA, Pomeroy et al. (2000) found a marked seasonal change in microbial respiratory rates in 5 Georgia estuaries but no clear seasonal change in respiratory rates in adjacent coastal water. Coastal water off southeastern USA appeared to have a higher and more constant rate of phytoplankton photosynthesis, while the estuary was dominated by heterotrophic processes in the intertidal sediments. These examples suggest the inherent complexity of substrate-temperature interactions.

Interaction of temperature with substrate concentrations also appears to occur with nitrifying bacteria, although, as above, the findings and interpretations are somewhat mixed. In a seasonal study at an organic-nutrient-poor site in Narragansett Bay, Berounsky \& Nixon (1990) found a strong relationship between nitrification and temperature, with rates approaching zero in winter and a $Q_{10}$ of 6.8. A more detailed study of nitrification in the Rhône estuary (Bianchi et al. 1999) concluded that rates were dependent only on salinity, although the graphics appear to show quite a strong seasonal cycle. Bianchi et al. criticized the methodology of Berounsky \& Nixon and questioned the high $Q_{10}$, citing 2 studies of isolates in culture, one of which (Helder \& de Vries 1983) examined temperature and substrate concentrations separately, while the other (Carlucci \& Strickland 1968) cultured only with excess substrate. From the present perspective, all of these studies of 1 factor at a time may have missed significant interactions.

Some of the controversy surrounding temperaturesubstrate interactions at low temperature has focused on research in Conception Bay, Newfoundland (Wiebe \& Pomeroy 2000). Pomeroy et al. (1991) postulated that changes in bacterial production in Conception Bay, which has a seasonal surface temperature range of -1.8 to $14^{\circ} \mathrm{C}$ and is thus a temperate body of water, could be produced by temperature-substrate interactions. Inferred low substrate concentrations at the onset of the spring phytoplankton bloom in late March, at a water temperature of $-1.8^{\circ} \mathrm{C}$, were postulated to result in low pre-bloom and early bloom rates of bacterial growth and respiration in late winter and early spring. Pomeroy et al. (1991) carried out experiments in which the natural microbial community in Conception Bay water at $-1.8^{\circ} \mathrm{C}$ was supplied with a range of concentrations of substrate, incubated at several temperatures, and changes in the microbial respiratory rate measured. Respiratory rates were found to increase with increases of either substrate concentration or temperature. Bacterial production was also mea- 
sured during the spring bloom, with water temperatures at the annual minimum (Pomeroy et al. 1991). The Tdr method showed low uptake at the start of the bloom, except at the depth of the chlorophyll maximum. Because Pomeroy et al. (1991) were using a final concentration of $5 \mathrm{nmol}$ Tdr and the Fuhrman \& Azam (1980) conversion factor, their Tdr uptake measurements probably underestimated bacterial production. Moreover, respiration and growth are different parameters of bacterial activity and are not necessarily correlated (Christian \& Wiebe 1974, Yager \& Deming 1999)

Rivkin et al. (1996) later measured bacterial production at the same Conception Bay station for $18 \mathrm{mo}$, also using $5 \mathrm{nmol} \mathrm{Tdr}$, but using dilution cultures each month to create a conversion factor. Rivkin et al. (1996) reported very little seasonal change in bacterial productivity in the mixed layer. However, their correction factors showed a seasonal trend, highest in winter, suggesting to us that bacterial substrate affinity must have been reduced in winter. Moreover, a new seasonal data set from nearby Logy Bay, Newfoundland (Putland 2000), using dilution culture estimates of bacterial production, showed a seasonal change in bacterial production of an order of magnitude and a substantial correlation with temperature $\left(\mathrm{r}^{2}=0.73\right)$. While Logy Bay is not a deep fjord like Conception Bay and contains water of somewhat different origins, this would seem at least to leave open the question of what is the normal seasonal regime of bacterial production in the Newfoundland fjords and coastal waters.

\section{Permanently cold waters}

A number of investigators have interpreted the work of Pomeroy et al. (1991) in Newfoundland as predicting low rates of bacterial production in polar waters, possibly because of the presence of the Labrador Current in Conception Bay and along the Newfoundland coast at depths below $125 \mathrm{~m}$ and the presence in spring of some sea ice and icebergs of more northern origin (e.g. Kottmeier \& Sullivan 1988, Robinson \& Williams 1993, Glud et al. 1998, Psenner \& Sattler 1998, Thamdrup \& Fleischer 1998). Moreover, several commentators have wrongly located Newfoundland in the Arctic (e.g. Delille \& Rosiers 1995, Nedwell 1999, 2000, Deming \& Huston 2000). At latitude $48^{\circ} \mathrm{N}$ (approximately equivalent to that of Seattle or Paris), Conception Bay has a marine temperate climate and a $15^{\circ} \mathrm{C}$ annual temperature range in the upper mixed layer. It is thus within the northern temperate latitudes, delineated in the original hypothesis of a differential rate of primary production and heterotrophic consumption during spring blooms (Pomeroy \& Wiebe 1988). The use of the term, 'cold-ocean paradigm' by Rivkin et al. (1996) to describe our hypothesis of temperature-substrate interaction directs attention toward low temperatures and away from interaction with substrates. Permanently cold environments, with an annual range in temperature $\leq 4^{\circ} \mathrm{C}$, which include the high polar regions and much of the deep ocean, represent, in some respects, a different case from seasonally cold temperate waters, a distinction recognized by Christian \& Wiebe (1974) and Karl (1993). In polar waters, and perhaps even in abyssal waters receiving a seasonal rain of detritus (Billett et al. 1983), there is evidence for a seasonal shift from a winter early bloom regime with little microbial activity to a summer late bloom regime, in which both zooplankton grazing and microbial loop activity are major processes (Turley \& Lochte 1990, Conover \& Huntley 1991, Thingstad \& Martinussen 1991, Carlson et al. 1998, Bird \& Karl 1999).

For more than $100 \mathrm{yr}$, investigators have known that some bacteria are capable of metabolic activity at temperatures as low as $0^{\circ} \mathrm{C}$ (Fischer 1888, ZoBell 1934). The earliest measurements of bacterial activity in polar seas, using radioactive substrate uptake as a proxy for activity, demonstrated a range of bacterial metabolic rates comparable to those found in temperate oceans (Gillespie et al. 1976, Morita et al. 1977). Virtually every measurement of polar summer bacterial activity since Morita's has shown growth rates within the normal summertime ranges found at all latitudes, and these measurements are now quite numerous. They include many measurements in water and sediments with an annual temperature range $\leq 4^{\circ} \mathrm{C}$. Bacterial metabolic activity in polar waters in winter in the marginal ice zone is sometimes similar to that of summer (Rivkin et al. 1989, Cota et al. 1990, Sullivan et al. 1990, Mordy et al. 1995). In other instances very low rates are seen, although little seasonal temperature change occurred (Griffiths et al. 1978, Pomeroy et al. 1990, Karl 1993, Carlson et al. 1998, Bird \& Karl 1999). Rates of bacterial growth and respiration may, of course, be limited by the availability of organic substrates, by the availability of inorganic nutrients (Reay et al. 1999, Kirchman 2000), or by interactions of both with temperature. Processes in the marginal ice zone, around the edge of sea ice, may be quite different from those in open ocean water. For example, an order of magnitude increase in chl a occurs near the ice in summer (cf. Fig. 1 of Le Fèvre et al. 1998).

To progress from simple experimental systems, such as those utilized by Quinlan $(1980,1981)$ and Harder \& Veldkamp (1971), who developed theoretical principles of temperature-substrate interaction, to interpretations of complex events in natural microbial communities is a considerable challenge. Although we can measure temperature easily, quantifying the sub- 
strates available to heterotrophs in natural waters or sediments remains impossible at present. Qualitatively, as noted above, some environments may contain excess substrates (e.g. most sediments, sediments suspended in water by wind or tide, water in some small or shallow lakes, regions of organic pollution) and therefore show less temperature sensitivity. Such excesses can, of course, be site-variable, as in the case of the subantarctic Marion Island lakes, where Robarts et al. (1991) found a lake enriched by seal feces to have high microbial activity, while an adjacent lake without seals did not. Moreover, if affinity for substrates is temperature-related, then at seasonally minimum temperatures there can be a pool of substrate that is labile but physiologically inaccessible to bacteria at those temperatures (Nedwell 2000).

In permanently cold surface waters with a temperature span $\leq 4^{\circ} \mathrm{C}$, the highly stenothermic isolate of Christian \& Wiebe (1974) showed that, given the appropriate substrate, it could remain active throughout the year. While temperature is always an underlying factor in metabolic activity, as Morita (1974) and others have demonstrated, it need not stop bacterial growth in polar waters. Fig 2 illustrates that bacteria in polar waters, at least those we have been able to culture, are always living at temperatures well below their optima for growth, which implies a higher concentration threshold for utilization of dissolved substrates. During polar winter, or under thick, snow-covered sea ice, substrate might become limiting, if the data of Pomeroy et al. (1990) and Wiebe et al. (1992) are generally applicable. The lack of any unusual accumulation of dissolved organic matter in polar seawater shows that marine heterotrophic bacteria do utilize labile DOC down to nanomolar concentrations at $-1.8^{\circ} \mathrm{C}$.

Microbial processes in the Arctic Ocean and the Southern Ocean appear to differ in some respects. Measurements of summertime rates of bacterial production and respiration in the Arctic Ocean suggest that bacterioplankton should exhaust the organic matter originating from autochthonous primary production well before the end of winter (Cota et al. 1996, Rich et al. 1997). Similarly, during winter in the Antarctic, Helmke \& Weyland (1995) found very low bacterial production beneath the pack ice. In contrast, Mordy et al. (1995) found that bacterial production in water near the ice margin during winter was equivalent to $44 \%$ of primary production. This bacterial activity in winter likely reflects the fact that there is some year-round phytoplankton photosynthesis in most of the Southern Ocean, and it is enhanced near the ice edge even in winter (Cota et al. 1992). Differences seen in winter microbial activity between the 2 polar regions may relate in large to differences in latitude. The high Arc- tic is in complete darkness for $3 \mathrm{mo}$, while only the most southern parts of the Southern Ocean are south of the Antarctic Circle. Thus, the different findings in Arctic versus Antarctic regions may result from seasonal changes in photosynthesis and the resultant substrate supply to an oligotrophic environment. The effects of temperature on polar photosynthesis have been variously interpreted (Neori \& Holm-Hansen 1982, Cota 1985, Tilzer et al. 1985, Kottmeier \& Sullivan 1987, Robinson et al. 1995), but it is clear that phytoplankton photosynthesis occurs near Antarctic ice margins essentially all year round.

Ice and snow cover also affect photosynthesis and thus substrate supply for bacterioplankton and other consumers. Pomeroy et al. (1990) attempted to measure production of heterotrophic bacterioplankton in June, before spring melt had begun, at the Canadian Ice Island (then located at $79^{\circ} 37.3^{\prime} \mathrm{N}, 108^{\circ} 51.2^{\prime} \mathrm{W}$ ), a drifting tabular iceberg in the Arctic Ocean north of Ellef Ringness Island. Because of its location in the Canadian Basin gyre, this region is covered by a mean ice thickness of $6 \mathrm{~m}$ (Maykut 1985). Except for scattered leads, water under the ice was still in darkness in June, and water temperature was $-1.8^{\circ} \mathrm{C}$. At an initial concentration of $5 \mathrm{nM} \mathrm{Tdr}$, bacterial production may have been underestimated, but if we assume underestimation by an order of magnitude, then the bacterial production under the ice in June was $270 \mu \mathrm{g} \mathrm{C} \mathrm{m}^{-3} \mathrm{~d}^{-1}$ near the surface and 1.1 at the top of the halocline. Such rates would be more than 3 orders of magnitude less than the mixed-layer rates measured by Rich et al. (1997) and Cota et al. (1996) in summer in the Chukchi Sea, so the measurements at the Ice Island in June suggest the presence of an inactive bacterial community prior to spring melt and the onset of summer primary production.

In the Antarctic, in the largely ice-covered Ross Sea, Carlson et al. (1998) found that pre-bloom DOC concentrations and bacterial production rates in surface water of the Ross Sea polynya were comparable to those at depths of $1000 \mathrm{~m}$ and were described as background rates. Two weeks later, during the Phaeocystis bloom, bacterial production had risen an order of magnitude, but concentrations of DOC were essentially unchanged, presumably because of rapid utilization by heterotrophs. Carlson et al. postulated that Antarctic bacterioplankton production is carbon-limited. In these polar situations with nearly invariant temperature, bacterioplankton are well below their temperature optimum, as illustrated by Fig. 2, and may therefore have a lower substrate affinity, or may have a long lag period before commencing growth (Lancelot et al. 1989, Ducklow 1999, Ducklow et al. 1999). Obviously, these problems do not prevent bacteria from maintaining viable populations and using all labile substrates. 
The results of the RACER program in Bransfield Strait, west of the Antarctic Peninsula (Karl et al. 1991, Karl 1993) present another case of low bacterial activity in spring. Although the annual cycle of abundance of biomass covered 2 orders of magnitude (Tien et al. 1992), and concentrations of free amino acids in the water were high (Haberstroh et al. 1987), bacterial production did not begin to rise from very low winter values until approximately a month after the onset of the spring bloom. Bird \& Karl (1991) suggested that temperature as such may be the underlying factor in the observed slow response. Karl (1993) suggested that DFAA may have been present in concentrations that saturated bacterial affinity during the bloom, so that temperature had no effect. Based on the model developed in their Fig. 2, observed dissolved free amino acid (DFAA) concentrations appear to have been, at most, sufficient to stimulate growth of psychrotolerant bacteria at $-1^{\circ} \mathrm{C}$ (Table 1$)$. Although winter data are relatively scarce in the high latitudes, they suggest that low or non-existent primary production during winter, depending on ice thickness and latitude, sometimes results in the reduction of available substrates to the minimal concentrations at which they can be assimilated from seawater, with bacteria entering the starvation-survival mode (Griffiths et al. 1978, Tien et al. 1992). An alternative hypothesis is that of Jumars et al. (1989) that most of the substrates resulting from blooms are released by the processing of phytoplankton by zooplankton, so a delay might occur between phytoplankton production and bacterial production because of the need for processing phytoplankton through the food chain.

While the magnitude of bacterial growth and metabolism must be directly or indirectly associated with the amount of primary production or chl a (Cole et al. 1988), there are times when, as in the Bransfield Strait, there is little direct relationship between primary producers and heterotrophic bacterial consumers, particularly at the onset of spring blooms (Azam et al. 1981, Billen \& Fontigny 1987, Lancelot et al. 1989, Pomeroy et al. 1991, Karl 1993, Bird \& Karl 1999) or later in summer (Fiala \& Delille 1992). While it is self-evident that phytoplankton provide the organic carbon for heterotrophic bacterial growth, it is clear that in many circumstances they do not do so directly to any large extent. Except when they are nutrient-limited or otherwise stressed, phytoplankton are often found to release as DOC $<15 \%$ of carbon fixed by photosynthesis (Larsson \& Hagström 1982, Wood et al. 1992, Murray 1995) — although this is highly variable. This potentially rapid transfer of organic matter from photoautotroph to bacterial consumer usually falls short of supplying enough organic carbon to meet the observed rates of bacterioplankton production and respiration, so additional connections between phytoplankton and bacterioplankton consumers have been proposed. Phytoplankton may lyse, either because of viral infections or as a result of the onset of nutrient deficiency (Agustí et al. 1998, Agustí \& Duarte 2000). Lysis can release DOC and POC to bacterioplankton consumers (Jassby \& Goldman 1974, Lancelot \& Billen 1984). As noted above, another trophic connection between phytoplankton and bacterioplankton is the excretion, defecation, and sloppy feeding of microzooplankton (Jumars et al. 1989) and protists (Sherr et al. 1982, Sherr \& Sherr 1989). Unlike the release of low molecular weight DOC during photosynthesis, both of the latter processes incur some delay between primary production and the availability of the DOC. In a broader sense, there is experimental support for the view that grazing, viral infection, or autolysis of phytoplankton is necessary for initiating significant bacterial activity for the microbial loop (reviewed by Nagata 2000).

The delay in the onset of bacterioplankton production following spring phytoplankton blooms, which Pomeroy \& Deibel (1986) suggested might be the result of a differential response of phytoplankton and bacteria to low spring temperatures, thus appears to be a frequent occurrence but to have multiple causes (Sherr \& Sherr 1996). A lag in the supply of suitable substrates may be a more significant deterrent to bacterioplankton production in those situations than seasonally low temperature. However, the lags between the peaks of phytoplankton and bacterioplankton production tend to be longer at higher latitudes, and experimental evidence suggests that production of the dominant bacterioplankton at high latitudes would be greater if the temperature were higher, although how much higher would seem to depend on local conditions. Li \& Dickie (1984) showed that the dominant bacteria in water samples in the Canadian Arctic survived and increased their metabolic rates when warmed to $30^{\circ} \mathrm{C}$. This response was also seen in the Arctic isolates of Wiebe et al. (1992), which had higher affinity for low concentrations of substrates at 15 to $30^{\circ} \mathrm{C}$ than at temperatures near $0^{\circ} \mathrm{C}$. Hodson et al. (1981) found maximum uptake rates for glucose, leu, Tdr, and ATP at $5^{\circ} \mathrm{C}$ during austral summer in McMurdo Sound, and Azam et al. (1981) found maximum uptake at $7^{\circ} \mathrm{C}$ in the Scotia Sea. Gillespie et al. (1976) found psychrophile dominance at some Antarctic stations and psychrotolerant dominance at others. Simon et al. (1999) found a gradient of bacterial temperature optima from $>18^{\circ} \mathrm{C}$ at the polar front to $4-8^{\circ} \mathrm{C}$ at the ice edge. The experiments of Harder \& Veldkamp (1971) and Helmke \& Weyland (1986) suggest how the history of a water mass and its bacterial flora may lead to different population trajectories in polar waters so that either psychrophiles or psychrotolerants may be locally dominant, especially 
during the polar summer. Additional limits, such as iron availability, also may control bacterial production in Antarctic waters (Pakulski et al. 1996).

\section{Sea ice}

Sea ice is a major component of both polar regions, covering millions of $\mathrm{km}^{2}$ even at the end of polar summer (Horner et al. 1992). It is variable in structure and content, depending on conditions under which it forms and melts, and there may even be characteristic differences between Arctic and Antarctic sea ice (Legendre et al. 1992). Sea ice is one of the coldest Earth environments, with temperatures $<-30^{\circ} \mathrm{C}$ near the upper surface during winter (Vincent 1988, Thomas et al. 1995). While living organisms can be found throughout sea ice, distinct communities tend to be concentrated in one or more horizontal bands in the most porous ice, either near bottom, near top, or near the level of the sea surface (Fritsen et al. 1994, Arrigo et al. 1998). Very high rates of primary production have been reported (McMinn et al. 2000). However, sea ice is a highly variable environment, and it is difficult to generalize about ice biota. Arrigo et al. (1998) approached this problem for Antarctic ice algae by modeling algal distribution in time and space. The complexities of the model included temperature, salinity, nutrients, photosynthetically active radiation and its modification by season, location, snow, ice, inclusions and biota. The model indicates that first-year ice supports $75 \%$ of total primary production in Antarctic ice, of which $50 \%$ is in the Weddell Sea. The model was insensitive to temperature, because the temperature range was small. A major variable was flooding resulting from snow loading, which renewed nutrients and increased primary production in the ice.

Most sea ice, whether it is land-fast or pack ice, is formed annually, and enclosed bacterial populations undergo a process of selection, based on their ability to sequester substrates at increasingly lower temperatures (Helmke \& Weyland 1995). Newly formed pancake ice contains largely psychrotolerant bacteria, while winter ice contains largely obligate psychrophiles (Grossmann 1994, Grossmann \& Dieckmann 1994, Helmke \& Weyland 1995). Phytoplankton undergo a similar selection, after which a few species appear to be responsible for most of the biomass and production. In winter, much of the biomass is in brine pockets within the central mass of the ice. In spring, a dense community sometimes develops at the bottom of the ice, where the ice algae can extract nutrients continuously from the underlying water. When the snow melts from the ice surface in spring, solar radiation begins to warm the brown, diatom-rich layer at the bottom of the ice, which then falls through the water, providing the first pulse of primary production in the water column. This process is especially characteristic of land-fast ice (Smith et al. 1988, Staley \& Gosink 1999). Pack ice sometimes develops a layer of algae in porous ice at the level of the water surface which persists into the polar summer and is released if the ice melts (Arrigo et al. 1998).

Because of the porosity of sea ice during its formation and degradation, the phytoplankton and bacteria, which grow in the ice as it freezes or erodes, accumulate nitrogen, phosphorus, and organic carbon from the water that is flowing past (Cota et al. 1987), similar to the way that communities of coral reefs concentrate nutrients from flowing oligotrophic water. Sea ice accumulates atmospheric fallout, although the quantitative significance of that source is unknown. 'Dirty ice' also accumulates inclusions of bottom sediments (Dayton et al. 1969) or suspended sediments (Sherwood 2000). In these ways, sea ice accumulates more organic matter than the underlying water. Also, as sea ice freezes and solidifies, salt, and probably DOC, are extruded into the sea, while salt and DOC are also concentrated in brine pockets which retain a functioning food web that recycles substrates and nutrients. Some of the psychrophiles in the brine pockets will function nearly down to a temperature at which virtually no liquid water remains (Staley \& Gosink 1999, Deming \& Huston 2000). Rivkina et al. (2000) found that little bacterial activity occurred in permafrost at temperatures less than $-10^{\circ} \mathrm{C}$, which they attribute to liquid-water problems. The few measurements of DOC and POC in sea ice suggest that its content varies widely, depending on the type of ice, layering within ice, its manner of formation, its current state of freezing or thawing, and the development, or not, of communities of living microorganisms. Grainger (1977) reported that inorganic nitrate and phosphate were concentrated in the lower layers of ice in Frobisher Bay but not near the top. Mel'nikov \& Pavlov (1978) found increased POC concentrations in Arctic sea ice but little increase in DOC. Pomeroy et al. (1990) found high concentrations of DFAAs in melting spring fast ice at Resolute, Nunavut, and Thomas et al. (1995) found high concentrations of DOC in multi-year ice in Fram Strait at 80 to $81^{\circ} \mathrm{N}$. These studies emphasize the inherent heterogeneity of sea ice that must result from different local conditions.

Bacterial production in Arctic fast ice in spring was found to be only $3 \%$ of the primary production within the ice (Smith et al. 1989). This is surprising, considering that DFAAs can be 3 orders of magnitude more concentrated in fast ice than in Arctic seawater (Pomeroy et al. 1990, Cota et al. 1996). It is not clear 
why the sea-ice bacteria cannot use a greater fraction of the accumulated DOC, assuming that they are in the same places within the ice.

Based on all of the information discussed above, we postulate that although bacteria can grow over part of the range of temperature of sea ice, they do not appear to be able to utilize available substrates below the high concentrations sometimes present in the ice. Deming \& Huston (2000) suggested that bacteria in sea ice produce copious amounts of exoenzymes to compensate for the suboptimal temperature. However, exoenzymes have been found to have activity optima even higher than those of psychrophilic bacteria (Helmke \& Weyland 1991, Vetter \& Deming 1994). Thus, the brine pockets within sea ice may accumulate high concentrations of amino acids because of reduced substrate affinity by heterotrophic bacteria. A number of investigators have concluded that low temperature is not limiting to ice bacteria because growth can be demonstrated throughout the winter. These investigators either conducted their experiments utilizing the naturally high substrate concentrations present in the sea ice environment or conducted experiments with conventional laboratory media, which have even higher substrate concentrations. Bacteria in sea ice are not absolutely growth-limited by temperature or substrate concentration (Smith et al. 1989, Cota et al. 1990, Helmke \& Weyland 1995, Delille \& Rosiers 1995), but clearly they would function better at an elevated temperature. Indeed, they do much better in surface meltwater ponds at temperatures near $0^{\circ} \mathrm{C}$ (Palmisano \& Garrison 1993).

\section{CONCLUSIONS}

1. Substrate concentration and temperature interact in all bacterial populations at all temperatures and substrate concentrations. Experimental evaluations of this interaction under conditions similar to those in natural waters are few, and the potential for such work may be limited by our ability to culture dominant groups of marine heterotrophic bacteria. Substratetemperature interactions appear to become a dominant factor in growth and fitness only at the extremes of the ranges of concentrations and/or temperatures in any environment where responses depart from Arrhenius Law relationships. This non-linear response tends to confuse interpretations of 'temperature effects' and correlations of other factors with temperature. The fact that we cannot, at present, quantitatively define the available substrate concentration for natural populations or communities of bacteria further exacerbates attempts to interpret our observations of real-world events.
2. Experimental data suggest that temperature-substrate relationships of heterotrophic bacteria differ with the temperature regime. Tropical organisms mostly function at, or near, their temperature optima for growth and assimilation. Temperate organisms, although there is acclimation and seasonal succession, operate relatively near their optima in summer and near their no-growth temperatures in winter, except when substrate concentrations are $\mathrm{mg} \mathrm{l}^{-1}$. In polar environments, psychrotolerant and psychrophilic bacteria operate far below their temperature optima at all times. Although the data are sparse, psychrophiles appear to become the dominant populations in sea ice.

3. Experiments with isolates indicate that continued growth at temperatures approaching those at which growth ceases requires an increase in substrate concentration of several orders of magnitude. Some attempts to ascertain temperature effects versus substrate concentration may have failed because an insufficient range of substrate concentrations was used.

4. Heterotrophic bacteria can physiologically adapt to low temperature in a variety of ways, all of which have limits (Nedwell 1999, 2000). At the freezing point of seawater, bacteria appear to function quite well, although there have been suggestions that their affinity for DFAAs is affected. At the temperatures experienced within sea ice, bacteria still function, at least down to $-5^{\circ} \mathrm{C}$, and probably somewhat lower. Their affinity for substrates at these temperatures may be strongly affected, as indicated by the residual concentrations of DFAAs and DOC in sea ice.

5. The one situation in nature where dissolved organic matter may accumulate at least in part because of the lower substrate affinity of heterotrophic bacteria is in sea ice. Some, but not all, of the very few measurements of DOC or DFAA in sea ice show concentrations orders of magnitude greater than in seawater. Additional data are needed.

6. Heterotrophic bacterial processes are ancient and fundamental components of virtually all extant ecosystems. It is difficult to conceive how an ecosystem without active heterotrophs would function, but the accumulation of dissolved amino acids in some sea ice is suggestive of a system-level problem that would arise without functioning heterotrophic bacteria. Although it has sometimes been suggested that bacteria are less active in polar oceans (e.g. Sorokin 1971), extant evidence suggests that with the possible exception of sea ice, inhibitory effects are not sufficient to alter overall ecosystem function.

Acknowledgements. We thank the following for critically reading drafts of this review: B. A. Biddanda, G. F. Cota, J. T. Hollibaugh, R. Y. Morita, D. B. Nedwell, J. D. Pakulski, J. K. Pomeroy, J. K. W. Wiegel, and 3 anonymous reviewers. Sup- 
port for this work was provided by US National Science Foundation grant OPP-9815763 to G. F. Cota.

\section{LITERATURE CITED}

Admiraal W, Beukema J, van Es FB (1985) Seasonal fluctuation in the biomass and metabolic activity of bacterioplankton and phytoplankton in a well-mixed estuary: the Ems-Dollard (Wadden Sea). J Plankton Res 7:877-890

Agustí M, Duarte C (2000) Strong seasonality in phytoplankton cell lysis in the northwest Mediterranean littoral. Limnol Oceanogr 45:940-947

Agustí S, Paola Satta M, Paola Mura M, Benavent E (1998) Dissolved esterase activity as an indicator of phytoplankton lysis: evidence of high phytoplankton lysis rates. Limnol Oceanogr 43:1836-1849

Arrigo K, Worthen DL, Dixon P, Lizotte MP (1998) Primary productivity of near surface communities within Antarctic pack ice. In: Lizotte MP, Arrigo K (eds) Antarctic sea ice, biological processes, interactions and variability. American Geophysical Union, Washington, p 23-43

Autio R (1998) Response of seasonally cold-water bacterioplankton to temperature and substrate treatments. Estuar Coast Shelf Sci 46:465-474

Azam F, Ammerman JW, Cooper N (1981) Bacterioplankton distributional patterns and metabolic activities in the Scotia Sea. Antarct J US 16:164-165

Behrenfield MJ, Bale AJ, Kolber ZS, Aiken J, Falkowski PG (1996) Confirmation of iron limitation of phytoplankton photosynthesis in the equatorial Pacific Ocean. Nature 383:508-511

Bell TR, Ahlgren I (1987) Thymidine incorporation and microbial respiration in the surface of a hypereutrophic lake. Limnol Oceanogr 32:476-482

Benner, R, Pakulski JD, McCarthy M, Hedges JI, Hatcher PG (1992) Bulk chemical characteristics of dissolved organic matter in the ocean. Science 255:1561-1564

Berounsky VM, Nixon SW (1990) Temperature and the annual cycle of nitrification in waters of Narragansett Bay. Limnol Oceanogr 35:1610-1617

Bianchi M, Feliatra, Lefevre D (1999) Regulation of nitrification in the land-ocean contact area of the Rhône River plume (NW Mediterranean). Aquat Microb Ecol 18: 301-312

Billen G, Fontigny A (1987) Dynamics of a Phaeocystis-dominated spring bloom in Belgian coastal waters. II. Bacterioplankton dynamics. Mar Ecol Prog Ser 37:249-257

Billett DSM, Lampitt RS, Rice AL, Mantoura RFC (1983) Seasonal sedimentation of phytoplankton to the deep-sea benthos. Nature 302:520-522

Bird DF, Karl DM (1991) Spatial patterns of glutamic and thymidine assimilation in Bransfield Strait, Antarctica during and following the austral spring bloom. Deep-Sea Res 38:1057-1075

Bird DF, Karl DM (1999) Uncoupling of bacteria and phytoplankton during the austral spring bloom in Gerlache Strait, Antarctic Peninsula. Aquat Microb Ecol 19:13-27

Børsheim KY (2000) Bacterial production rates and concentrations of organic carbon at the end of the growing season in the Greenland Sea. Aquat Microb Ecol 21:115-123

Burney CM, Davis PG, Johnson KM, Sieburth JMcN (1981) Dependence of dissolved carbohydrate concentrations upon small scale nanoplankton and bacterioplankton distributions in the Western Sargasso Sea. Mar Biol 65: 289-296

Burney CM, Davis PG, Johnson KM, Sieburth JMcN (1982)
Diel relationships of microbial trophic groups and in situ dissolved carbohydrate dynamics in the Caribbean Sea. Mar Biol 67:311-322

Button DK (1986) Affinity of organisms for substrate. Limnol Oceanogr 31:453-456

Button DK, Schut F, Quang P, Martin RM, Robertson B (1993) Viability and isolation of typical marine oligobacteria by dilution culture: theory, procedures, and initial results. Appl Environ Microbiol 41:936-941

Button DK, Robertson BR, Lepp PW, Schmidt TM (1998) A small, dilute-cytoplasm, high-affinity, novel bacterium isolated by extinction culture and having kinetic constants compatible with growth at ambient concentrations of dissolved nutrients in seawater. Appl Environ Microbiol 64: 4467-4476

Carlson CA, Ducklow HW, Hansell DA, Smith WO Jr (1998) Organic carbon partitioning during spring phytoplankton blooms in the Ross Sea polynya and the Sargasso Sea. Limnol Oceanogr 43:375-386

Carlucci AF, Strickland JDH (1968) The isolation, purification and some kinetic studies of marine nitrifying bacteria. J Exp Mar Biol Ecol 2:156-166

Carney JF, Colwell RR (1976) Heterotrophic utilization of glucose and glutamate in an estuary: effect of season and nutrient load. Appl Environ Microbiol 31:227-233

Chranowski TH (1988) Consequences of accounting for isotopic dilution in thymidine incorporation assays. Appl Environ Microbiol 54:1868-1870

Christian RR, Wiebe WJ (1974) The effects of temperature upon the reproduction and respiration of a marine obligate psychrophile. Can J Microbiol 20:1341-1345

Chróst RJ (1990) Application of the isotope dilution principals to the determination of substrate incorporation by aquatic bacteria. Arch Hydrobiol Beih Ergebn Limnol 34:111-117

Coffin RB (1989) Bacterial uptake of free and combined dissolved amino acids in estuarine waters. Limnol Oceanogr 34:531-542

Cole JJ, Findlay S, Pace ML (1988) Bacterial production in fresh and saltwater ecosystems: a cross-system overview. Mar Ecol Prog Ser 43:1-10

Conover RJ, Huntley M (1991) Copepods in ice-covered seas - distribution, adaptations to seasonally limited food, metabolism, growth patterns and life cycle strategies in polar seas. J Mar Syst 2:1-41

Cota GF (1985) Photoadaptation of high Arctic ice algae. Nature 315:219-222

Cota GF, Prinsenberg SJ, Bennett EB, Loder JW, Lewis MR, Anning JL, Watson NHF, Harris LR (1987) Nutrient fluxes during extended blooms of Arctic ice algae. J Geophys Res 92:1951-1962

Cota GF, Kottmeier ST, Robinson DH, Smith WO Jr, Sullivan CW (1990) Bacterioplankton in the marginal ice zone of the Weddell Sea: biomass, production and metabolic activities during austral autumn. Deep-Sea Res 37: 1145-1167

Cota GF, Smith WO, Nelson DM, Gordon LI, Muench R (1992) Nutrient and biogenic particulate distributions, primary productivity and nitrogen uptake in the Weddell-Scotia Sea marginal ice zone during winter. J Mar Res 50: $155-181$

Cota GF, Pomeroy LR, Harrison WG, Jones EP, Peters F, Sheldon WM Jr, Weingartner TR (1996) Nutrients, primary production and microbial heterotrophy in the southeastern Chukchi Sea: Arctic summer nutrient depletion and heterotrophy. Mar Ecol Prog Ser 135: 247-258

Cotner JB, Johengen TH, Biddanda BA (2000) Intense winter heterotrophic production stimulated by benthic resuspen- 
sion. Limnol Oceanogr 45:1672-1676

Cronin TM, Raymo ME (1997) Orbital forcing of deep-sea benthic species diversity. Nature 385:624-627

Dayton PK, Robillard GA, DeVries AL (1969) Anchor ice formation in McMurdo Sound, Antarctica, and its biological effects. Science 163:273-274

Delille D, Rosiers C (1995) Seasonal changes of Antarctic marine bacterioplankton and sea ice bacterial assemblages. Polar Biol 16:27-34

DeLong EF, Wu KY, Prézelin BB, Jovine RVM (1994) High abundance of Archaea in Antarctic marine picoplankton. Nature 371:695-697

Deming JW, Huston AL (2000) An oceanographic perspective on microbial life at low temperatures. In: Seckbath J (ed) Cellular origins and life in extreme habitats. Kluwer, Dordrecht

Deming JW, Yager PL (1992) Natural bacterial assemblages in deep-sea sediments: towards a global view. In: Rowe GT, Pariente V (eds) Deep-sea food chains and the global carbon Cycle. Kluwer, Dordrecht, p 11-27

Ducklow HW (1999) The bacterial component of the oceanic euphotic zone. FEMS Microbiol Ecol 30:1-10

Ducklow HW, Shiah FK (1993) Estuarine bacterial production. In: Ford TE (ed) Aquatic microbiology, an ecological approach. Blackwell, Boston, p 261-287

Ducklow HW, Carlson CA, Smith WO (1999) Bacterial growth in experimental plankton assemblages and seawater cultures from the Phaeocystis antarctica bloom in the Ross Sea, Antarctica. Aquat Microbl Ecol 19:215-227

Eilers H, Pernthaler J, Amann R (2000) Succession of pelagic marine bacteria during enrichment: a close look at cultivation-induced shifts. Appl Environ Microbiol 66:4634-4640

Felip M, Pace ML, Cole JJ (1996) Regulation of bacterial growth rates: the effects of temperature and resources. Microb Ecol 31:15-28

Fiala M, Delille D (1992) Variability and interactions of phytoplankton and bacterioplankton in the Antarctic neritic area. Mar Ecol Prog Ser 89:135-146

Fischer B (1888) Baketerienwachstum bei $0^{\circ} \mathrm{C}$ sovie über des Photographien von Kulturen leuchender Bakterien in ihren einige Lichte. Centralbl Bakteriol 4:89-92

Fritsen CH, Lytle VI, Ackley SF, Sullivan CW (1994) Autumn bloom of Antarctic pack-ice algae. Science 266:782-784

Fuhrman JA (1992) Novel major archaebacterial group from marine plankton. Nature 356:148-149

Fuhrman JA, Azam F (1980) Bacterioplankton secondary production estimates for coastal waters of British Columbia, Antarctica and California. Appl Environ Microbiol 39: 1085-1095

Fuhrman JA, Azam F (1983) Adaptations of bacteria to marine subsurface waters studied by temperature response. Mar Ecol Prog Ser 13:95-98

Fuhrman JA, McCallum K, Davis AA (1993) Phylogenetic diversity of subsurface marine microbial communities from the Atlantic and Pacific oceans. Appl Environ Microbiol 59:1294-1302

Gillespie PA, Morita RY, Jones LP (1976) The heterotrophic activity for amino acids, glucose and acetate in Antarctic waters. J Oceanogr Soc Jpn 32:74-82

Giovannoni SJ, Britschgi TB, Mayer CL, Field KG (1993) Genetic diversity in Sargasso Sea bacterioplankton. Nature 345:60-63

Glud RN, Hoffmann OH, Canfield DE (1998) Benthic mineralization and exchange in Arctic sediments (Svalbard, Norway). Mar Ecol Prog Ser 173:237-251

González JM, Moran MA (1997) Numerical dominance of a group of marine bacteria in the $\alpha$-subclass of the class Pro- teobacteria in coastal seawater. Appl Environ Microbiol 63:4237-4242

González JM, Whitman WB, Hodson RE, Moran MA (1996) Identifying numerically abundant culturable bacteria from complex communities: an example from a lignin enrichment culture. Appl Environ Microbiol 62:4433-4440

Grainger EH (1977) The annual nutrient cycle in sea ice. In: Dunbar MJ (ed) Polar oceans. Arctic Inst N Amer, Calgary, p 285-299

Griffiths RP, Hayasaka SS, McNamara TM, Morita RY (1978) Relative microbial activity and bacterial concentrations in water and sediment samples taken in the Beaufort Sea. Can J Microbiol 24:1217-1226

Griffiths RP, Caldwell BA, Morita RY (1982) Seasonal changes in microbial heterotrophic activity in subarctic marine waters as related to phytoplankton primary productivity. Mar Biol 71:121-127

Griffiths RP, Caldwell BA, Morita RY (1984) Observations on microbial percent respiration values in Arctic and subarctic marine waters and sediments. Microb Ecol 10:151-164

Grossmann S (1994) Bacterial activity in sea ice and open water of the Weddell Sea, Antarctica: a microautoradiographic study. Microb Ecol 28:1-8

Grossmann S, Dieckmann GS (1994) Bacterial standing stock, activity, and carbon production during formation and growth of sea ice in the Weddell Sea, Antarctica. Appl Environ Microbiol 60:2746-2753

Haberstroh PR, Bailiff MD, Tien G, Taylor GT, Jones D, Tilbrook B, Nawrocki M, Karl DM (1987) RACER: dissolved free amino acid concentrations, molecular composition, and microbial uptake rates in the Bransfield Strait. Antarct J US 22:153-156

Hagström $\AA$, Larsson U (1984) Diel and seasonal variation in growth rates of pelagic bacteria. In: Hobbie JE, Williams PJleB (eds) Heterotrophic activity in the sea. Plenum Press, New York, p 249-262

Hagström ^, Pinhassi J, Zweifel UL (2000) Biogeographical diversity among marine bacterioplankton. Aquat Microb Ecol 21:231-244

Hansell DA, Bates NR, Gundersen K (1995) Mineralization of dissolved organic carbon in the Sargasso Sea. Mar Chem 51:201-212

Harder W, Veldkamp H (1971) Competition of marine psychrophilic bacteria at low temperature. Antonie Leeuwenhoek 37:51-63

Helder W, de Vries RTP (1983) Estuarine nitrite maxima and nitrifying bacteria (Ems-Dollard estuary). Neth J Sea Res $17: 1-18$

Helmke E, Weyland H (1986) Effect of hydrostatic pressure and temperature on the activity and synthesis of chitinases of Antarctic Ocean bacteria. Mar Biol 91:1-7

Helmke E, Weyland H (1991) Effect of temperature on extracellular enzymes occurring in permanently cold marine environments. Kiel Meeresforsch Sonderh 8:198-204

Helmke E, Weyland H (1995) Bacteria in sea ice and underlying water of the eastern Weddell Sea in midwinter. Mar Ecol Prog Ser 117:269-287

Henrichs SM, Williams PM (1985) Dissolved and particulate amino acids and carbohydrates in the sea surface microlayer. Mar Chem 17:141-163

Hodson RE, Azam F, Carlucci AF, Karl DM, Holm-Hansen O (1981) Microbial uptake of dissolved organic matter in McMurdo Sound, Antarctica. Mar Biol 61:89-94

Hollibaugh JT (1979) Metabolic adaptation in natural bacterial populations supplemented with selected amino acids. Estuar Coast Mar Sci 9:215-230

Horner R, Ackley SF, Dieckmann GS, Gulliksen B, Hoshiai T, 
Legendre L, Melnikov IA, Reeburgh WS, Spindler M, Sullivan CW (1992) Ecology of sea ice biota. 1. Habitat, terminology, and methodology. Polar Biol 12:417-427

Jannasch HW, Jones GE (1959) Bacterial populations in sea water as determined by different methods of enumeration. Limnol Oceanogr 4:128-139

Jassby AD, Goldman CR (1974) Loss rates from a lake phytoplankton community. Limnol Oceanogr 19:618-627

Jumars PA, Penry DL, Baross JA, Perry MJ, Frost BW (1989) Closing the microbial loop: dissolved carbon pathway to heterotrophic bacteria from incomplete ingestion, digestion and absorption in animals. Deep-Sea Res 36:483-495

Karl DM (1993) Microbial processes in the southern oceans. In: Friedmann EI (ed) Antarctic microbiology. Wiley-Liss, New York, p 1-63

Karl DM, Holm-Hansen O, Taylor GT, Tien G, Bird DF (1991) Microbial biomass and productivity in the western Bransfield Strait, Antarctica during the 1986-87 austral summer. Deep-Sea Res 38:1029-1055

Keil R, Kirchman DL (1991) Dissolved combined amino acids in marine waters as determined by vapor-phase hydrolysis. Mar Chem 33:243-259

Kirchman DL (2000) Uptake and regeneration of inorganic nutrients by marine heterotrophic bacteria. In: Kirchman DL (ed) Microbial ecology of the oceans. Wiley-Liss, New York, p 261-288

Kirchman DL, Ducklow HW, Mitchell R (1982) Estimates of bacterial growth from changes in uptake rates and biomass. Appl Environ Microbiol 44:1296-1307

Kottmeier ST, Sullivan CW (1987) Late winter primary production and bacterial production in sea ice and seawater west of the Antarctic Peninsula. Mar Ecol Prog Ser 36: 287-298

Kottmeier ST, Sullivan CW (1988) Sea ice microbial communities (SIMCO) 9. Effects of temperature and salinity on rates of metabolism and growth of autotrophs and heterotrophs. Polar Biol 8:293-304

Laanbroek HJ, Verplanke JC, de Visscher PRM, de Vuyst R (1985) Distribution of phyto- and bacterioplankton growth and biomass parameters, dissolved organic nutrients and free amino acids during a spring bloom in the Oosterschelde basin, The Netherlands. Mar Ecol Prog Ser 25: $1-11$

Lancelot C, Billen G (1984) Activity of heterotrophic bacteria and the coupling to primary production during the spring phytoplankton bloom in the southern bight of the North Sea. Limnol Oceanogr 29:721-730

Lancelot C, Billen G, Mathot S (1989) Ecophysiology of phytoand bacterioplankton growth in the Southern Ocean. Final report to Belgian Program of Scientific Research on the Antarctic, Groupe de Microbiologie des Milieux Aquatiques, Université Libre de Bruxelles

Larsson U, Hagström $\AA$ (1982) Fractionated phytoplankton primary production, exudate release and bacterial production in a Baltic eutrophication gradient. Mar Biol 67: $57-70$

Le Fèvre J, Legendre L, Rivkin R (1998) Fluxes of biogenic carbon in the Southern Ocean: role of large macrophagous zooplankton. J Mar Syst 17:325-345

Legendre L, Ackley SF, Dieckmann GS, Gulliksen B, Horner R, Hoshiai T, Melnikov IA, Reeburgh WS, Spindler M, Sullivan CW (1992) Biology of sea ice biota. 2. Global significance. Polar Biol 12:429-444

Li WKW, Dickie PM (1984) Rapid enhancement of heterotrophic but not photosynthetic activities in Arctic microbial plankton at mesobiotic temperatures. Polar Biol 3:217-226 Li WKW, Dickie PM (1987) Temperature characteristics of photosynthetic and heterotrophic activities - seasonal variations in temperate microbial plankton. Appl Environ Microbiol 53:2282-2295

Liebig J (1840) Organic chemistry and its applications to agriculture and physiology. Taylor and Walton, London

Logan B, Fleury RC (1993) Multiphasic kinetics can be an artifact of the assumption of saturable kinetics for microorganisms. Mar Ecol Prog Ser 102:115-124

Malone TC, Ducklow HW (1990) Microbial biomass in the coastal plume of Chesapeake Bay: phytoplankton-bacterioplankton relationships. Limnol Oceanogr 35:296-312

Maykut GA (1985) The sea ice environment. In: Horner RA (ed) Sea ice biota. CRC Press, Boca Raton, FL, p 21-82

McMinn A, Ashworth C, Ryan KG (2000) In situ primary productivity of an Antarctic fast ice bottom algal community. Aquat Microb Ecol 21:177-185

Mel'nikov IA, Pavlov GL (1978) Characteristics of organic carbon distribution in the waters and ice of the Arctic basin. Oceanology (AGU English edn) 18:163-167

Mopper K, Lindroth P (1982) Diel and depth variations in dissolved free amino acids and ammonium in the Baltic Sea determined by shipboard HPLC analysis. Limnol Oceanogr 27:336-347

Mordy CW, Penny DM, Sullivan CW (1995) Spatial distribution of bacterioplankton biomass and production in the marginal ice zone of the Weddell-Scotia Sea during austral winter. Mar Ecol Prog Ser 122:9-19

Morita RY (1974) Temperature effects on marine microorganisms. In: Colwell RR, Morita RY (eds) Effect of the ocean environment on microbial activities. University Park Press, Baltimore, p 75-79

Morita RY, Buck GE (1974) Low temperature inhibition of substrate uptake. In: Colwell RR, Morita RY (eds) Effect of the ocean environment on microbial activities. University Park Press, Baltimore, p 124-129

Morita RY, Griffiths RP, Hayasaka SS (1977) Heterotrophic activity of microorganisms in Antarctic waters. In: Llano GA (ed) Adaptations within Antarctic ecosystems. Smithsonian, Washington, p 99-113

Morris DP, Lewis WM Jr (1992) Nutrient limitation of bacterioplankton growth in Lake Dillon, Colorado. Limnol Oceanogr 37:1179-1192

Murray AG (1995) Phytoplankton exudation: exploitation of the microbial loop as a defense against algal viruses. J Plankton Res 17:1079-1094

Nagata T (2000) Production mechanisms of dissolved organic matter. In: Kirchman DL (ed) Microbial ecology of the oceans. Wiley-Liss, New York, p 121-152

Nedwell DB (1999) Effect of low temperature on microbial growth: lowered affinity for substrates limits growth at low temperature. FEMS Microbiol Ecol 30:101-111

Nedwell DB (2000) Life in the cooler — starvation in the midst of plenty; and implications for microbial polar life. In: Bell CR, Brylinsky M, Johnson-Green P (eds) Microbial biosystems: new frontiers. Atlantic Canada Society for Microbial Ecology, Halifax, p 299-305

Nedwell DB, Rutter M (1991) Influence of temperature on growth rate and competition between two psychrotolerant Antarctic bacteria: low temperature diminishes affinity for substrate uptake. Appl Environ Microbiol 60:1984-1992

Neori A, Holm-Hansen O (1982) Effect of temperature on rate of photosynthesis in Antarctic phytoplankton. Polar Biol 1: 33-38

Nielsen TG, Richardson K (1989) Food chain structure of the North Sea plankton community: seasonal variations in the role of the microbial loop. Mar Ecol Prog Ser 56:75-87

Novitsky JA, Morita RY (1976) Morphological characteriza- 
tion of small cells resulting from nutrient starvation of a psychrophile marine Vibrio. Appl Environ Microbiol 32: $617-622$

Pakulski JD, Benner R (1994) Abundance and distribution of carbohydrates in the ocean. Limnol Oceanogr 39:930-940

Pakulski JD, Coffin R, Kelley C, Holder S (1996) Iron stimulation of Antarctic marine bacteria. Nature 383:133-134

Palmisano AC, Garrison DL (1993) Microorganisms in sea ice. In: Friedmann EI (ed) Antarctic microbiology. Wiley-Liss, New York, p 167-218

Pinhassi J, Hagström Å (2000) Seasonal succesion in marine bacterioplankton. Aquat Microb Ecol 21:245-256

Pinhassi J, Zweifel UL, Hagström Å (1997) Dominant marine bacterioplankton species found among colony-forming bacteria. Appl Environ Microbiol 63:3359-3366

Pomeroy LR, Deibel D (1986) Temperature regulation of bacterial activity during the spring bloom in Newfoundland coastal waters. Science 233:359-361

Pomeroy LR, Wiebe WJ (1988) Energetics of microbial food webs. Hydrobiologia 159:7-18

Pomeroy LR, Macko SA, Ostrom PH, Dunphy J (1990) The microbial food web in Arctic seawater: concentration of dissolved fee amino acids and bacterial abundance and activity in the Arctic Ocean and in Resolute Passage. Mar Ecol Prog Ser 61:31-40

Pomeroy LR, Wiebe WJ, Deibel D, Thompson RJ, Rowe GT, Pakulski JD (1991) Bacterial responses to temperature and substrate concentration during the Newfoundland spring bloom. Mar Ecol Prog Ser 75:143-159

Pomeroy LR, Sheldon JE, Sheldon WM Jr, Peters F (1995) Limits to growth and respiration of bacterioplankton in the Gulf of Mexico. Mar Ecol Prog Ser 117:259-268

Pomeroy LR, Sheldon JE, Sheldon WM Jr, Blanton JO, Amft J, Peters F (2000) Seasonal changes in microbial processes in estuarine and continental shelf waters of the southeastern U.S.A. Estuar Coast Shelf Sci 51:415-428

Poremba K, Dürselen CD, Stoeck T (1999) Succession of bacterial abundance, activity, and temperature adaptation during winter 1996 in parts of the German Wadden Sea and adjacent coastal waters. J Sea Res 42:1-10

Poulet SA, Williams R, Conway DVP, Videau C (1991) Cooccurrence of copepods and dissolved free amino acids in shelf sea waters. Mar Biol 108:373-385

Proctor LM, Fuhrman JA (1990) Viral mortality of marine bacteria and cyanobacteria. Nature 343:60-62

Psenner R, Sattler B (1998) Life at the freezing point. Science 280:2071-2072

Putland JN (2000) Microzooplankton herbivory in Newfoundland coastal waters during spring, summer and winter. J Plankton Res 22:253-277

Quinlan AV (1980) The thermal sensitivity of MichaelisMenten kinetics as a function of substrate concentration. J Franklin Inst 310:325-342

Quinlan AV (1981) The thermal sensitivity of generic Michaelis-Menten processes without catalyst denaturation or inhibition. J Therm Biol 6:103-114

Reay DS, Nedwell DB, Priddle J, Ellis-Evans JC (1999) Temperature dependence of inorganic nitrogen uptake: reduced affinity for nitrate at suboptimal temperatures in both algae and bacteria. Appl Environ Microbiol 65: $2577-2584$

Rehnstam AS, Bäckman S, Smith DC, Azam F, Hagström ^̊ (1993) Bloom of sequence-specific culturable bacteria in the sea. FEMS Microbiol Ecol 102:161-166

Reitner B, Herzig A, Herndl GJ (1997) Microbial activity under the ice cover of the shallow Neuseidler See (Austria, central Europe). Hydrobiologia 357:173-184
Rex MA, Stuart CT, Hessler RR, Allen JA, Sanders HL, Wilson GDF (1993) Global-scale latitudinal patterns of species diversity in the deep-sea benthos. Nature 365:636-639

Rich J, Kirchman DL, Gosselin M, Sherr E, Sherr B (1997) High bacterial production, uptake and concentrations of dissolved organic matter in the central Arctic Ocean. Deep-Sea Res II 44:1645-1663

Rivkin RB, Putt M, Alexander SP, Meritt D, Gaudet L (1989) Biomass and production in polar planktonic and sea ice microbial communities: a comparative study. Mar Biol 101: 273-283

Rivkin RB, Anderson MR, Gustafson DE Jr (1991) Dynamics of bacterioplankton growth in McMurdo Sound, Antarctica: evidence for substrate sufficient growth. Antarctic J US 26:145-146

Rivkin RB, Anderson MR, Lajzerowicz C (1996) Microbial processes in cold oceans. 1. Relationship between temperature and bacterial growth rate. Aquat Microb Ecol 10: $243-254$

Rivkina EM, Friedmann EI, McKay CP, Gilichinsky DA (2000) Metabolic activity of permafrost bacteria below the freezing point. Appl Environ Microbiol 66:3230-3233

Robarts RD, Sephton LM, Wicks RJ (1991) Labile dissolved organic carbon and water temperature as regulators of heterotrophic bacterial activity and production in the lakes of sub-Antarctic Marion Island. Polar Biol 11: 403-413

Robinson C, Williams PJleB (1993) Temperature and Antarctic plankton community respiration. J Plankton Res 15: 1035-1051

Robinson DH, Arrigo KR, Iturriaga R, Sullivan CW (1995) Microalgal light-harvesting in extreme low-light environments in McMurdo Sound, Antarctica. J Phycol 31: 508-520

Romankevich EA (1984) Geochemistry of organic matter in the ocean. Springer, Berlin

Ruger HJ, Tan TL (1992) Community structure of cold and low-nutrient adapted sediment bacteria from the deep eastern tropical Atlantic. Mar Ecol Prog Ser 84:83-93

Rutter M, Nedwell DB (1994) Influence of changing temperature on growth rate and competition between two psychrotolerant Antarctic bacteria: competition and survival in non-steady-state temperature environments. Appl Environ Microbiol 60:1993-2002

Ryther JH, Dunstan WM (1971) Nitrogen, phosphorus, and eutrophication in the coastal marine environment. Science 171:1008-1012

Scavia D, Laird GA (1987) Bacterioplankton in Lake Michigan: dynamics, controls, and significance to carbon flux. Limnol Oceanogr 32:1017-1033

Senior W, Chevolot L (1991) Studies of dissolved carbohydrates (or carbohydrate-like substances) in an estuarine environment. Mar Chem 32:19-35

Sherr B, Sherr E (1989) Trophic impacts of phagotrophic protozoa in pelagic foodwebs. In: Hattori $\mathrm{T}$, Ishida $\mathrm{Y}$, Maruyama Y, Morita RY, Uchida A (eds) Recent advances in microbial ecology. Japan Scientific Societies Press, Tokyo, p 388-392

Sherr B, Sherr E, Berman T (1982) Decomposition of organic detritus: a selective role for microflagellate Protozoa. Limnol Oceanogr 27:765-769

Sherr EB, Sherr BF (1996) Temporal offset in oceanic production and respiration processes implied by seasonal changes in atmospheric oxygen: the role of heterotrophic microbes. Aquat Microb Ecol 11:91-100

Sherwood CR (2000) Numerical model of frazil ice and suspended sediment concentrations and formation of sedi- 
ment-laden ice in the Kara Sea. J Geophys Res 105: 14061-14080

Shiah FK, Ducklow HW (1994a) Temperature and substrate regulation of bacterial abundance, production and specific growth rate in Chesapeake Bay, USA. Mar Ecol Prog Ser 103:297-308

Shiah FK, Ducklow HW (1994b) Temperature regulation of heterotrophic bacterioplankton abundance, production and specific growth rate in Chesapeake Bay, USA. Limnol Oceanogr 39:1243-1258

Sieburth JMcN (1967) Seasonal selection of estuarine bacteria by water temperature. J Exp Mar Biol Ecol 1:98-121

Simon M, Glöckner FO, Amann R (1999) Different community structure and temperature optima of heterotrophic picoplankton in various regions of the Southern Ocean. Aquat Microb Ecol 18:275-284

Smith REH, Anning J, Clement P, Cota GF (1988) Abundance and production of ice algae in Resolute Passage, Canadian Arctic. Mar Ecol Prog Ser 48:251-263

Smith REH, Clement P, Cota GF (1989) Population dynamics of bacteria in Arctic sea ice. Microb Ecol 17:63-76

Søndergaard M, Williams PJL, Cauwet G, Riemann B, Robinson C, Terzic S, Woodward EMS, Worm J (2000) Net accumulation and flux of dissolved organic carbon and dissolved organic nitrogen in marine plankton communities. Limnol Oceanogr 54:1097-1111

Sorokin Y (1971) On the role of bacteria in the productivity of tropical ocean waters. Int Rev Ges Hydrobiol 56:1-48

Staley JT, Gosink JJ (1999) Poles apart: biodiversity and biogeography of sea ice bacteria. Annu Rev Microbiol 53: 189-215

Stanley SO, Boto KG, Alongi DM, Gillan FT (1987) Composition and bacterial utilization of free amino acids in tropical mangrove sediments. Mar Chem 22:13-30

Sullivan CW, Cota GF, Krempin DW, Smith WO Jr (1990) Distribution and activity of bacterioplankton in the marginal ice zone of the Weddell-Scotia Sea during austral spring. Mar Ecol Prog Ser 63:239-252

Thamdrup B, Fleischer S (1998) Temperature dependence of oxygen respiration, nitrogen mineralization, and nitrification in Arctic sediments. Aquat Microb Ecol 15:191-199

Thingstad TF, Lignell R (1997) A theoretical approach to the question of how trophic interactions control carbon demand, growth rate, abundance, and diversity. Aquat Microb Ecol 13:19-27

Thingstad TF, Martinussen I (1991) Are bacteria active in the cold pelagic ecosystem of the Barents Sea? Polar Res 10: 255-266

Thomas DN, Lara RJ, Eiken H, Kattner G, Skoog A (1995) Dissolved organic matter in Antarctic multi-year sea ice during winter: major components and relationship to ice characteristics. Polar Biol 15:477-483

Thurman EM (1985) Organic geochemistry of natural waters. Nijhoff/Junk, Dordrecht

Tien G, Burgett J, Dore J, Geren M, Houlihan T, Letelier R, Magaard U, Parrish G, Szyper J, Karl D (1992) Seasonal variability in microbial biomass in the Gerlache Strait: a feast-or-famine existence. Antarct J US 27:166-167

Tilzer MM, von Bodungen B, Smetacek V (1985) Light dependence of phytoplankton photosynthesis in the Antarctic Ocean: implications for regulating productivity. In: Siegfried WR, Condy PR, Laws RM (eds) Antarctic nutrient cycles and food webs. Springer, Berlin, p 60-69

Turley CM, Lochte K (1990) Microbial response to the input of fresh detritus to the deep sea bed. Paleogeogr Paleoclimatol Paleoecol 89:3-23

Upton AC, Nedwell DB (1989a) Temperature responses of bacterial isolates from different Antarctic environments. In: Haywood RB (ed) University research in Antarctica: Proceedings of the British Antarctic Survey Special Topic Award Scheme Symposium. British Antarctic Survey, Cambridge, p 97-101

Upton AC, Nedwell DB (1989b) Nutritional flexibility of oligotrophic and copiotrophic Antarctic bacteria with respect to organic substrates. FEMS Microbiol Ecol 62:1-6

van Looij A, Riemann B (1993) Measurements of bacterial production in coastal marine environments using leucine: application of a kinetic approach to correct for isotope dilution. Mar Ecol Prog Ser 102:97-104

Vetter YA, Deming JW (1994) Extracellular enzyme activity in the Arctic Northeast Water polynya. Mar Ecol Prog Ser 114:23-34

Vincent WF (1988) Microbial ecosystems of Antarctica. Cambridge University Press, Cambridge

Weiss M, Simon M (1999) Consumption of labile dissolved organic matter by limnetic bacterioplankton: the relative significance of amino acids and carbohydrates. Aquat Microb Ecol 17:1-12

White PA, Kalff J, Rasmussen JB, Gasol JM (1991) The effect of temperature and algal biomass on bacterial production and specific growth rate in freshwater and marine habitats. Microb Ecol 21:99-118

Wiebe WJ, Hendricks CW (1974) Distribution of heterotrophic bacteria in a transect of the Antarctic Ocean. In: Colwell RR, Morita RY (eds) Effect of the ocean environment on microbial activities. University Park Press, Baltimore, p 524-535

Wiebe WJ, Pomeroy LR (1972) Microorganisms and their association with aggregates and detritus in the sea: a microscopic study. Mem Ist Ital Idrobio 29(Suppl):325-352

Wiebe WJ, Pomeroy LR (2000) The temperature-substrate controversy resolved? In: Bell CR, Brylinsky M, JohnsonGreen P (eds) Microbial biosystems: new frontiers. Atlantic Canada Society for Microbial Ecology, Halifax, p 695-699

Wiebe WJ, Smith DF (1977) Direct measurement of dissolved organic carbon release by phytoplankton and incorporation by microheterotrophs. Mar Biol 42:213-223

Wiebe WJ, Sheldon WM Jr, Pomeroy LR (1992) Bacterial growth in the cold: evidence for an enhanced substrate requirement. Appl Environ Microbiol 58:359-364

Wiebe WJ, Sheldon WM Jr, Pomeroy LR (1993) Evidence for an enhanced substrate requirement by marine mesophilic bacterial isolates at minimal growth temperatures. Microb Ecol 25:151-159

Williams PJleB (2000) Heterotrophic bacteria and the dynamics of dissolved organic material. In: Kirchman DL (ed) Microbial ecology of the oceans. Wiley-Liss, New York, p 153-200

Wood AM, Rai H, Garnier J, Kairesalo T, Gresens S, Orive E, Ravail B (1992) Practical approaches to algal excretion. Mar Microb Food Webs 6:21-38

Yager PL, Deming JW (1999) Pelagic microbial activity in an arctic polynya: testing for temperature and substrate interactions using a kinetic approach. Limnol Oceanogr 44: 182-193

ZoBell C (1934) Microbiological activities at low temperatures with particular reference to marine bacteria. Q Rev Biol 9: 460-466

Submitted: September 6, 2000; Accepted: December 15, 2000 Proofs received from author(s): January 18, 2001 